Efficient cartridge purification for producing high molar activity [18F]fluoro-glycoconjugates via oxime formation

\title{
Keinänen, Outi
}

2018

Keinänen , O , Partelová , D , Alanen , O , Antopolsky , M , Sarparanta , M \& Airaksinen , A J 2018 , ' Efficient cartridge purification for producing high molar activity

[18F]fluoro-glycoconjugates via oxime formation ' , Nuclear Medicine and Biology , vol. 67 , pp. 27-35 . https://doi.org/10.1016/j.nucmedbio.2018.10.001

http://hdl.handle.net/10138/328164

https://doi.org/10.1016/j.nucmedbio.2018.10.001

cc_by_nc_nd

acceptedVersion

Downloaded from Helda, University of Helsinki institutional repository.

This is an electronic reprint of the original article.

This reprint may differ from the original in pagination and typographic detail.

Please cite the original version. 
Efficient cartridge purification for producing high molar activity ${ }^{18} \mathrm{~F}$-glycoconjugates via oxime formation

Abbreviated title ( $\max 45$ letters and spaces): High molar activity ${ }^{18} \mathrm{~F}$-glycoconjugates with cartridge purification

Outi Keinänen, ${ }^{1}$ Denisa Partelová,,${ }^{1,2}$ Osku Alanen, ${ }^{1}$ Maxim Antopolsky, ${ }^{3}$ Mirkka Sarparanta, ${ }^{1}$ Anu J. Airaksinen ${ }^{1, *}$

${ }^{1}$ Department of Chemistry - Radiochemistry, University of Helsinki, Helsinki, Finland

${ }^{2}$ Department of Ecochemistry and Radioecology, Faculty of Natural Sciences, University of Ss. Cyril and Methodius in Trnava, Trnava, Slovakia

${ }^{3}$ Division of Pharmaceutical Biosciences, Faculty of Pharmacy, University of Helsinki, Helsinki, Finland

For correspondence contact: Anu Airaksinen, Department of Chemistry - Radiochemistry, University of Helsinki, POB 55, FI-00014 University of Helsinki, Finland

Phone number: +358294150124

Email: anu.airaksinen@helsinki.fi

keywords (max 6): aminooxy, cartridge purification, click reaction, fluorine-18, glycoconjugate, oxime formation 
Abstract: Introduction: ${ }^{18} \mathrm{~F}$-fluoroglycosylation via oxime formation is a chemoselective and mild radiolabeling method for sensitive molecules. Glycosylation can also improve the bioavailability, in vivo kinetics, and stability of the compound in blood, as well as accelerate clearance of biomolecules. A typical synthesis procedure for ${ }^{18} \mathrm{~F}$-fluoroglycosylation with $\left[{ }^{18} \mathrm{~F}\right] \mathrm{FDG}$ (2-deoxy-2- $\left[{ }^{18} \mathrm{~F}\right]$ fluoro-Dglucose) and $\left[{ }^{18} \mathrm{~F}\right] \mathrm{FDR}$ (5-deoxy-5-[ $\left.{ }^{18} \mathrm{~F}\right]$ fluoro-D-ribose) involves two HPLC (high performance liquid chromatography) purifications: one after ${ }^{18} \mathrm{~F}$-fluorination of the carbohydrate to remove its labeling precursor, and a second one after the oxime formation step to remove the aminooxy precursor. The two HPLC purifications can be time consuming and complicate the adaptation of the synthetic strategy in nuclear medicine applications and automated synthesis. We have developed a procedure in which SPE (solid phase extraction) and resin purification methods replace both of the needed HPLC purification steps.

Methods: We used $\left[{ }^{18} \mathrm{~F}\right] \mathrm{FDR}$ and $\left[{ }^{18} \mathrm{~F}\right] \mathrm{FDG}$ as prosthetic groups to radiolabel two aminooxymodified model molecules, a tetrazine and a PSMA (prostate specific membrane antigen) inhibitor. After fluorination, the excess carbohydrate precursor was removed by derivatizing it with 4,4'dimethoxytrityl chloride (DMT-Cl). The DMT moiety increases the hydrophobicity of the unreacted precursor making the separation from the fluorinated precursor possible with simple C18 Sep-Pak cartridge. For removal of the aminooxy precursor, we used a commercially available aldehyde resin (AminoLink, Thermo Fisher Scientific). C18 Sep-Pak SPE cartridge was used to separate $\left[{ }^{18}\right.$ F]FDR and $\left[{ }^{18} \mathrm{~F}\right] \mathrm{FDG}$ from the ${ }^{18} \mathrm{~F}$-fluoroglycoconjugate end product.

Results: $\left[{ }^{18} \mathrm{~F}\right] \mathrm{FDR}$ and $\left[{ }^{18} \mathrm{~F}\right] \mathrm{FDG}$ were efficiently purified from their precursors, free fluorine-18, and other impurities. The aldehyde resin quantitatively removed the unreacted aminooxy precursors after the oxime formation. The fluorine-18 labeled oxime end products were obtained with high radiochemical purity (> 99\%) and molar activity (> $600 \mathrm{GBq} / \mu \mathrm{mol})$.

Conclusions: We have developed an efficient cartridge purification method for producing high molar activity ${ }^{18} \mathrm{~F}$-glycoconjugates synthesized via oxime formation. 


\section{$\underline{\text { Introduction }}$}

${ }^{18}$ F-fluoroglycosylation has become a useful tool in fluorine-18 labeling. It has been used for the production of various ${ }^{18} \mathrm{~F}$-glycoconjugates, of for example of peptides, proteins, and other compounds, which are vulnerable to harsh reaction conditions [1-26]. Glycosylation also has a favorable impact on the biodistribution and cellular uptake properties of the radiotracer. The introduction of a carbohydrate moiety can improve the bioavailability, in vivo kinetics, stability in blood, and accelerate clearance of biomolecules conjugated with sugars [13, 27-34]. ${ }^{18} \mathrm{~F}$ fluoroglycosylation can be achieved with several methods but it is most frequently carried out via oxime formation, or by using other click reactions such as copper-catalyzed azide-alkyne cycloaddition (CuAAC). Advantages of the click glycosylation methods are their high chemoselectivity and the fact that they can be performed in aqueous solutions with high radiochemical yields. The downside, however, is that they require a preparative HPLC purification before the oxime formation step in order to remove the excess carbohydrate precursor. Due to the high concentration of glucose in the commercially available $\left[{ }^{18} \mathrm{~F}\right] \mathrm{FDG}$ (2-deoxy-2-[ $\left.{ }^{18} \mathrm{~F}\right]$ fluoro-Dglucose) formulations, clinical grade $\left[{ }^{18} \mathrm{~F}\right] \mathrm{FDG}$ is also usually purified with preparative HPLC before use in ${ }^{18} \mathrm{~F}$-fluoroglycosylation reactions. In order to produce high apparent molar activity end products, another HPLC purification is required after the ${ }^{18} \mathrm{~F}$-fluoroglycosylation to remove the excess aminooxy functionalized precursor of the second reaction step. The two HPLC purifications can be time consuming and will complicate the automation of the radiosynthesis for clinical production.

Oxime formation is a click reaction between aminooxy and carbonyl groups. $\left[{ }^{18} \mathrm{~F}\right] \mathrm{FDG}$ and $\left[{ }^{18} \mathrm{~F}\right] \mathrm{FDR}$ (5-deoxy-5-[ $\left.{ }^{18} \mathrm{~F}\right]$ fluoro-D-ribose) can be used as prosthetic groups to radiolabel wide variety of molecules by attaching aminooxy functional group to the desired molecule. The reaction with $\left[{ }^{18} \mathrm{~F}\right] \mathrm{FDG}$ often requires harsher reaction conditions (high temperature, low $\mathrm{pH}$ ) than reaction with $\left[{ }^{18} \mathrm{~F}\right] \mathrm{FDR}$. Both $\left[{ }^{18} \mathrm{~F}\right] \mathrm{FDG}$ and $\left[{ }^{18} \mathrm{~F}\right] \mathrm{FDR}$ isomerize between $\alpha$ - and $\beta$-anomer through intermediate 
acyclic aldehyde (Scheme 1, $\left[{ }^{18} \mathrm{~F}\right] \mathbf{3}$ and $\left[{ }^{18} \mathrm{~F}\right] \mathbf{1 0}$ ). This mutarotation has a dynamic equilibrium that is favored at high temperatures and for $\left[{ }^{18} \mathrm{~F}\right] \mathrm{FDG}$ it is more efficient at acidic conditions. In $\left[{ }^{18} \mathrm{~F}\right] \mathrm{FDR}$, the fluorine in $\mathrm{C}-5$ of the 5-membered ring prompts the formation of the acyclic form, making it more exposed for subsequent reaction to yield the oxime ether. For this reason, reactions with $\left[{ }^{18} \mathrm{~F}\right] \mathrm{FDR}$ can be carried out at room temperature even at pH 6 with high yields [23].

Recently, we published a radiosynthesis where $\left[{ }^{18} \mathrm{~F}\right] \mathrm{FDR}$ is used to radiolabel an aminooxyfunctionalized tetrazine [35]. Tetrazines are base-labile molecules that do not tolerate the typical conditions for nucleophilic ${ }^{18} \mathrm{~F}$-fluorination well. The developed synthesis involved two preparative HPLC purifications. The first one after the ${ }^{18} \mathrm{~F}$-fluorination step, and a second one after the oxime formation step. Here, our aim is to develop an HPLC-free purification method, which would be applicable for $\left[{ }^{18} \mathrm{~F}\right]$ fluoroglycosylation reactions with both $\left[{ }^{18} \mathrm{~F}\right] \mathrm{FDR}$ and $\left[{ }^{18} \mathrm{~F}\right] \mathrm{FDG}$. This was achieved by developing efficient cartridge-based procedures for both purification steps (Figure 1). The first HPLC purification was replaced by a DMT-Cl (4,4'-dimethoxytrityl chloride) derivatization, followed by subsequent C18 Sep-Pak cartridge separation. DMT-Cl is commonly used in nucleoside and nucleotide chemistry to protect alcohol groups $[36,37]$. Here we used the same method for conversion of the unreacted carbohydrate precursor to a more hydrophobic derivative, resulting in increased retention of the unreacted precursor complex in a regular C18 Sep-Pak cartridge and allowing its efficient separation from the ${ }^{18} \mathrm{~F}$-fluorinated carbohydrate. For the second purification step, the removal of the aminooxy precursor, we used a commercially available aldehyde resin (AminoLink, Thermo Fisher Scientific). The AminoLink resin is commonly used to purify biomolecules containing amine groups with reductive amination with cyanoborohydride $\left(\mathrm{NaCNBH}_{3}\right)$ in order to react the amine groups with the aldehyde groups on the resin [38]. In our protocol, the precursor contains an aminooxy group that rapidly reacts with the aldehyde groups without the need of any additional reagents. The AminoLink resin quantitatively trapped the unreacted aminooxy precursor, resulting in end products with high apparent molar activity. This is a significant 
improvement as due to their similar retention properties in cartridge separation systems based on hydrophobic interaction or size exclusion between the stationary phase and the analyte, it has not been previously possible to separate the aminooxy precursor and the oxime end product using such methods.

Recently, radiosynthesis of $\left[{ }^{18} \mathrm{~F}\right] \mathrm{FDG}$ conjugated PSMA (prostate specific membrane antigen) inhibitor was published by Wuest and his group. Since high apparent molar activity was required, HPLC purification was needed for removing the non-radiolabeled glucose-conjugates from the final product [3]. We tested our methodology by radiolabeling two different aminooxy functionalized compounds, the PSMA inhibitor with both $\left[{ }^{18} \mathrm{~F}\right] \mathrm{FDR}$ and $\left[{ }^{18} \mathrm{~F}\right] \mathrm{FDG}$ and a tetrazine for bioorthogonal radiolabeling using the inverse electron-demand Diels-Alder (IEDDA) reaction. The final radiolabeled products were characterized for radiochemical purity $(\%)$, molar activity $\left(\mathrm{GBq} \mu \mathrm{mol}^{-1}\right)$ and amount of residual organic impurities. The ${ }^{18} \mathrm{~F}$-fluoroglycosylated end products were efficiently separated from free $\left[{ }^{18} \mathrm{~F}\right]$ fluoride, the radiolabeling precursors $\left[{ }^{18} \mathrm{~F}\right] \mathrm{FDR}$ and $\left[{ }^{18} \mathrm{~F}\right] \mathrm{FDG}$, and nonradiolabeled organic impurities yielding the end products with $>99 \%$ radiochemical purity $(\mathrm{RCP})$

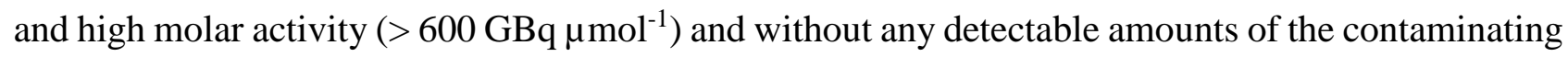
non-radioactive carbohydrate conjugates.

\section{Materials and methods}

Unless otherwise noted, all reagents were purchased from commercial suppliers and used without further purification. All water used was ultrapure (> $\left.18.2 \mathrm{M} \Omega \mathrm{cm}^{-1}\right)$. Reference compound 6, and precursors $\mathbf{1}$ and $\mathbf{4}$ were synthesized according to previously described procedures [24, 35].

Chemical and radiochemical purities were analyzed with analytical HPLC on a Shimadzu Prominence UFLC liquid chromatography system (Shimadzu Corporation, Kyoto, Japan) consisting of two LC20AD pumps, SIL-20AHT autosampler, CTO-20AC column oven, SPD-20A UV/VIS detector (dual 
mode with wavelengths $209 \mathrm{~nm}$ and $254 \mathrm{~nm}$ ) and an external $\mathrm{NaI}$ scintillation crystal radiodetector (Ortec, Oak Ridge, TN, USA) operated at $+0.90 \mathrm{kV}$. Separation was carried out on a Grace Alltima C18 column $(5 \mu \mathrm{m}, 250 \mathrm{~mm} \times 4.6 \mathrm{~mm})$ with a flow rate of $1 \mathrm{ml} \mathrm{min}^{-1}$. The used HPLC eluents were A: $0.1 \%$ TFA (trifluoroacetic acid) in water and B: 0.1\% TFA in acetonitrile. For compounds 3-7 and 10-12, the gradient was 5 to $50 \% \mathrm{~B}(0-15 \mathrm{~min})$. Retention times: $3.5 \mathrm{~min}\left(\left[{ }^{18} \mathrm{~F}\right] \mathbf{3}\right), 10.9 \mathrm{~min}(\mathbf{4})$, $5.9 \min (\mathbf{5}), 11.8 \min (\mathbf{6} E), 12.1 \min (\mathbf{6} Z), 6.6 \min (\mathbf{7} E), 7.0 \min (\mathbf{7} Z), 3.1 \min \left(\left[{ }^{18} \mathrm{~F}\right] \mathbf{1 0}\right), 11.2 \min$ (11 cyclic), $11.4 \min (\mathbf{1 1} E), 11.5 \min (\mathbf{1 1} Z), 6.2 \min (\mathbf{1 2}$ cyclic), $6.5 \min (\mathbf{1 2} E), 6.7 \min (\mathbf{1 2} Z), 4.2$ (pyridine), and $6.0 \mathrm{~min}$ (aniline). For compounds $\mathbf{1},\left[{ }^{18} \mathrm{~F}\right] \mathbf{2}, \mathbf{8}$, and $\left[{ }^{18} \mathrm{~F}\right] \mathbf{9}$, the gradient was 40 to $80 \%$ B (0-15 $\min )$. Retention times: $14.0 \min (\mathbf{1}), 9.0 \min \left(\left[{ }^{18} \mathrm{~F}\right] 2\right), 11.9 \min (\mathbf{8}), 8.7 \min \left(\left[{ }^{18} \mathrm{~F}\right] \mathbf{9}\right)$, and 3.0 $\min$ (pyridine).

Thin layer chromatography was performed using acetonitrile-water (95:5) eluent and TLC Merck Silica gel $60 \mathrm{~F}_{254}$ plates. The TLC plates were imaged with digital autoradiography on a FLA-5000 scanner (Fujifilm, Japan) at a nominal resolution of $50 \mu \mathrm{m}$. Autoradiographic images were analyzed using AIDA 2.0 software (Raytest Isotopenmessgeräte $\mathrm{GmbH}$, Straubenhardt, Germany). R $\mathrm{f}_{\mathrm{f}}$ values: $0.94\left(\left[{ }^{18} \mathrm{~F}\right] \mathbf{2}\right), 0.45\left(\left[{ }^{18} \mathrm{~F}\right] \mathbf{3}\right), 0.64\left(\left[{ }^{18} \mathrm{~F}\right] \mathbf{6}\right), 0.0\left(\left[{ }^{18} \mathrm{~F}\right] 7\right), 0.98\left(\left[{ }^{18} \mathrm{~F}\right] \mathbf{9}\right), 0.41\left(\left[{ }^{18} \mathrm{~F}\right] \mathbf{1 0}\right), 0.63\left(\left[{ }^{18} \mathrm{~F}\right] \mathbf{1 1}\right)$, and $0.0\left(\left[{ }^{18} \mathrm{~F}\right] \mathbf{1 2}\right)$.

Radiosyntheses were carried out in a semi-automated synthesis unit (DM Automation, Stockholm, Sweden). ${ }^{18}$ F-Fluoride was produced on an IBA Cyclone $10 / 5$ cyclotron in a ${ }^{18} \mathrm{O}(\mathrm{p}, \mathrm{n}){ }^{18} \mathrm{~F}$ reaction.

${ }^{1} \mathrm{H}$ - and ${ }^{13} \mathrm{C}-\mathrm{NMR}$ spectra were recorded on a Varian Mercury 300 spectrometer at $27{ }^{\circ} \mathrm{C}$. Chemical shifts are reported in ppm $(\delta)$ relative to tetramethylsilane (TMS) and calibrated using solvent residual peaks or TMS as internal standard. Data are shown as follows: chemical shift, multiplicity (s = singlet, $\mathrm{d}=$ doublet, $\mathrm{t}=$ triplet, $\mathrm{q}=$ quartet, quin = quintet, $\mathrm{dd}=$ doublet of doublets, $\mathrm{dt}=$ doublet of triplets, $\mathrm{m}=$ multiplet $)$, integration, and coupling constant $(\mathrm{J}, \mathrm{Hz})$.

Bruker Daltonics micrOTOF (TOF-ESI-MS) was used for exact mass measurements. 
AminoLink coupling resin was purchased from Thermo Fisher Scientific. The AminoLink column for radiosynthesis was prepared on the day of use as follows. Polyethylene frit was placed on a $2 \mathrm{ml}$ syringe without a plunger. The frit was wetted with acetonitrile, and $0.5 \mathrm{ml}$ of AminoLink resin ( $1 \mathrm{ml}$ slurry) was added. The resin was washed with $6 \mathrm{ml}$ of water, and capped until use.

\section{$\underline{\text { Synthesis of aminooxy precursor } 5}$}

(Boc-aminooxy)acetic acid $(0.1187 \mathrm{~g}, 620.9 \mu \mathrm{mol}, 1.5 \mathrm{eq})$ was dissolved in $0.5 \mathrm{ml}$ of dimethylformamide (DMF) under argon atmosphere. 1-[Bis(dimethylamino)methylene]-1H-1,2,3triazolo[4,5-b]pyridinium 3-oxid hexafluorophosphate (HATU) (0.2418 g, $635.9 \mu$ mol, 1.6 eq) was added to the reaction vial. The mixture was let to stir for 10 minutes before adding di-tert-butyl ((6amino-1-(tert-butoxy)-1-oxohexan-2-yl)carbamoyl)glutamate $(0.1980 \mathrm{~g}, 406.0 \mu \mathrm{mol}, 1 \mathrm{eq})$ with 0.8 $\mathrm{ml}$ of DMF. The mixture was let to stir for 20 minutes before adding $N, N$-diisopropylethylamine (DIEA) $(180 \mu \mathrm{l}, 1033.4 \mu \mathrm{mol}, 2.5 \mathrm{eq})$. After 20 hours $15 \mathrm{ml}$ of ethyl acetate was added to the mixture. Extractions were done to remove DMF: 3 x $15 \mathrm{ml} 5 \% \mathrm{LiCl}$, and $20 \mathrm{ml}$ brine. The organic layer was dried with $\mathrm{MgSO}_{4}$ and evaporated to dryness. The crude product was dissolved in acetonitrile and purified with HPLC. Separation was carried out on a Grace Alltima C18 column $(5 \mu \mathrm{m}, 250 \mathrm{~mm} \times$

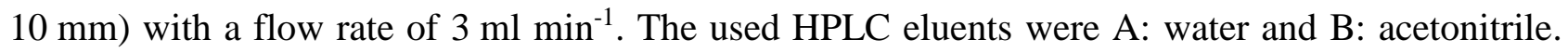
The gradient program was 0-3 min: $40 \% \mathrm{~B}, 3-15 \mathrm{~min}$ : 40 to $80 \% \mathrm{~B}, 15-25 \mathrm{~min}: 80 \% \mathrm{~B}$. Retention time was 19.2 min. After solvent removal by lyophilization the Boc-aminooxy intermediate was isolated as white powder (160.1 mg, $242.3 \mu \mathrm{mol}, 59.7 \%)$. TOF-ESI-MS [M+H] ${ }^{+} \mathrm{m} / z$ calcd. 661.4018 for $\mathrm{C}_{31} \mathrm{H}_{56} \mathrm{~N}_{4} \mathrm{O}_{11}$, found 661.3756. ${ }^{1} \mathrm{HNMR}\left(300 \mathrm{MHz}, \mathrm{CDCl}_{3}\right) \delta$ : 8.11 (s, 1H), 7.91 (bs, 1H), 5.32$5.37(\mathrm{~m}, 2 \mathrm{H}), 4.34(\mathrm{~s}, 2 \mathrm{H}), 4.24-4.40(\mathrm{~m}, 2 \mathrm{H}) 3.20-3.43(\mathrm{~m}, 2 \mathrm{H}), 2.23-2.40(\mathrm{~m}, 2 \mathrm{H}), 2.01-2.12(\mathrm{~m}$, $1 \mathrm{H}), 1.72-1.90(\mathrm{~m}, 2 \mathrm{H}), 1.49(\mathrm{~s}, 9 \mathrm{H}), 1.46(\mathrm{~s}, 9 \mathrm{H}), 1.45(\mathrm{~s}, 9 \mathrm{H}), 1.44(\mathrm{~s}, 9 \mathrm{H}), 1.22-1.68(\mathrm{~m}, 5 \mathrm{H}) .{ }^{13} \mathrm{C}-$ NMR (300 MHz, $\left.\mathrm{CDCl}_{3}\right) \delta: 172.81,172.57,169.32,157.89,157.23,83.07,82.20,81.63,80.66$, $75.96,53.50,53.10,38.34,32.31,31.74,28.83,28.50,28.28,28.21,28.16,22.23$. 
Boc-aminooxy intermediate $(128.4 \mathrm{mg}, 194.3 \mu \mathrm{mol})$ was dissolved in $30 \mathrm{ml}$ of $2 \mathrm{M} \mathrm{HCl}$ in $\mathrm{Et}_{2} \mathrm{O}$. The mixture was stirred at r.t. for 20 hours. The resulting white precipitate was isolated, dissolved in water, and purified with HPLC. Separation was carried out on a Grace Alltima C18 column (5 $\mu \mathrm{m}$, $250 \mathrm{~mm} \times 4.6 \mathrm{~mm}$ ) with a flow rate of $1 \mathrm{ml} \mathrm{min}^{-1}$. The used HPLC eluents were A: $0.1 \%$ TFA in water and B: $0.1 \%$ TFA in acetonitrile. The gradient was 5 to $50 \%$ B (0-15 min). Retention time: 5.9 min. After solvent removal by lyophilization the aminooxy precursor $\mathbf{5}$ was isolated as white powder (70.6 mg, $179.9 \mu \mathrm{mol}, 92.6 \%$ ). TOF-ESI-MS $[\mathrm{M}+\mathrm{H}]^{+} \mathrm{m} / z$ calcd. 393.1616 for $\mathrm{C}_{14} \mathrm{H}_{25} \mathrm{~N}_{4} \mathrm{O}_{9}$, found 393.1640. ${ }^{1} \mathrm{HNMR}(300 \mathrm{MHz}, \mathrm{D} 2 \mathrm{O}) \delta$ : 4.65 (s, 2H), 4.29-4.33 (dd, 1H, J = 5.2 Hz, J = 9.2 Hz), 4.22$4.26(\mathrm{dd}, 1 \mathrm{H}, \mathrm{J}=5.1 \mathrm{~Hz}, \mathrm{~J}=8.9 \mathrm{~Hz}), 3.29(\mathrm{t}, 2 \mathrm{H}, \mathrm{J}=7.0), 2.54(\mathrm{t}, 2 \mathrm{H}, \mathrm{J}=7.1 \mathrm{~Hz}), 2.17-2.29(\mathrm{~m}, 1 \mathrm{H})$, 1.98-2.08 (m, 1H), 1.85-1.95 (m, 1H) 1.70-1.81 (m, 1H), 1.57-1.66 (m, 2H), 1.41-1.51 (m, 2H).

\section{Synthesis of reference compound 7}

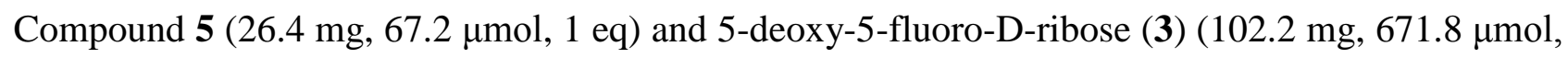
$10 \mathrm{eq}$ ) were dissolved in $1 \mathrm{ml}$ of water. The mixture was kept at r.t. (room temperature) for 1 hour. The product was purified with HPLC. Separation was carried out on a Grace Alltima C18 column $(5 \mu \mathrm{m}, 250 \mathrm{~mm} \times 4.6 \mathrm{~mm})$ with a flow rate of $1 \mathrm{ml} \mathrm{min}^{-1}$. The used HPLC eluents were A: $0.1 \%$ TFA in water and B: $0.1 \%$ TFA in acetonitrile. The gradient was 5 to $50 \% \mathrm{~B}$ (0-15 min). Retention time: $6.6 \mathrm{~min}(E)$ and $7.0 \mathrm{~min}(Z)$. After solvent removal by lyophilization compound 7 was isolated as white powder (28.2 mg, $53.6 \mu \mathrm{mol}$, yield 79.9\%, purity 99\% (HPLC $209 \mathrm{~nm})$ ). Compound 7 has an imine double bond and exists as $E / Z$ isomers. The two product peaks were observed with HPLC. The peaks were collected and subjected to TOF-ESI-MS. MS analysis confirmed the same mass for both peaks. Cyclic form was not detected which was in accordance with previous studies with FDR [20, $23,35]$.

TOF-ESI-MS $[\mathrm{M}+\mathrm{Na}]^{+} \mathrm{m} / z$ calcd. 549.1815 for $\mathrm{C}_{19} \mathrm{H}_{31} \mathrm{FN}_{4} \mathrm{O}_{12} \mathrm{Na}$, found 549.1816. ${ }^{1} \mathrm{H}-\mathrm{NMR}(300$ $\left.\mathrm{MHz}, \mathrm{D}_{2} \mathrm{O}\right) \delta: 7.74(\mathrm{~d}, 0.85 \mathrm{H}(E), \mathrm{J}=5.6 \mathrm{~Hz}), 7.06(\mathrm{~d}, 0.15 \mathrm{H}(Z), \mathrm{J}=6.2 \mathrm{~Hz}), 5.19-5.14(\mathrm{~m}, 0.15 \mathrm{H}$ $(Z)), 4.61(\mathrm{~s}, 0.3 \mathrm{H}(Z)), 4.60(\mathrm{~s}, 1.7 \mathrm{H}(E)), 4.65-4.57(\mathrm{~m}, 1.85 \mathrm{H}), 4.57-4.51(\mathrm{~m}, 1 \mathrm{H}), 4.35-4.27(\mathrm{~m}$, 
2H), 4.27-4.19 (m, 2H), 4.01-3.81 (m, 2H), $3.29(\mathrm{t}, 2 \mathrm{H}, \mathrm{J}=6.8 \mathrm{~Hz}), 2.56(\mathrm{t}, 2 \mathrm{H}, \mathrm{J}=7.3 \mathrm{~Hz}), 2.30-$ $2.14(\mathrm{~m}, 1 \mathrm{H}), 2.09-1.94(\mathrm{~m}, 1 \mathrm{H}), 1.94-1.81(\mathrm{~m}, 1 \mathrm{H}), 1.81-1.67(\mathrm{~m}, 1 \mathrm{H}), 1.67-1.51(\mathrm{~m}, 2 \mathrm{H}), 1.51-1.36$ (m, 2H). ${ }^{13} \mathrm{C}-\mathrm{NMR}\left(300 \mathrm{MHz}, \mathrm{D}_{2} \mathrm{O}\right) \delta: 177.67,177.54,176.67,172.31,159.74,154.09(Z), 153.24$ $(E), 86.11,83.92,72.61(E), 72.52(Z), 72.37(E), 70.48(Z), 70.24(Z), 69.73(E), 53.58,52.98,39.10$, $30.94,30.47,28.23,26.65,22.63$.

\section{Synthesis of reference compound $\mathbf{1 1}$}

Compound 4 (12.3 mg, $47.3 \mu \mathrm{mol}, 1$ eq) and 2-deoxy-2-fluoro-D-glucose (10) (77.6 mg, $426.0 \mu \mathrm{mol}$, 9 eq) were dissolved in $1.5 \mathrm{ml}$ of water. The mixture was kept at r.t. for 3 hours. The mixture was passed through the AminoLink (AL) resin ( $1 \mathrm{ml}$ of slurry, $0.5 \mathrm{ml}$ of resin, preconditioned with $6 \mathrm{ml}$ of water. Additional $2 \mathrm{ml}$ of water was passed through the AL resin after the application of the reaction mixture. The mixture was passed through C18 Sep-Pak cartridge (Waters, preconditioned with $5 \mathrm{ml}$ of ethanol and $10 \mathrm{ml}$ of water), and the cartridge was washed with $10 \mathrm{ml}$ of water. The product was eluted out with $5 \mathrm{ml}$ of acetonitrile and evaporated to dryness to yield the product as pink solid (14.6 mg, $34.4 \mu \mathrm{mol}$, yield 72.8\%, purity 99\% (HPLC $209 \mathrm{~nm}$ )). Three product peaks were observed with HPLC. The peaks were collected and subjected to TOF-ESI-MS. MS analysis confirmed identical mass for all peaks. The peaks belong to the acyclic $E$ - and $Z$-isomers, and the cyclic pyranose isomer. Previous studies have also reported the formation of different isomers with hexose conjugates $[14,17,18,39]$.

TOF-ESI-MS $[\mathrm{M}+\mathrm{H}]^{+} m / z$ calcd. 425.1579 for $\mathrm{C}_{17} \mathrm{H}_{22} \mathrm{FN}_{6} \mathrm{O}_{6}$, found $425.1586 .{ }^{1} \mathrm{H}-\mathrm{NMR}(300 \mathrm{MHz}$, DMSO) $\delta: 10.57(\mathrm{~s}, 1 \mathrm{H}), 8.54(\mathrm{t}, 0.14 \mathrm{H}(\mathrm{Z}), \mathrm{J}=6.2 \mathrm{~Hz}), 8.45(\mathrm{~d}, 2 \mathrm{H}, \mathrm{J}=8.3 \mathrm{~Hz}), 8.45(\mathrm{dd}, 0.58 \mathrm{H}$ $(E), \mathrm{J}=9.0,3.6 \mathrm{~Hz}), 7.76(\mathrm{t}, 0.58 \mathrm{H}(E), \mathrm{J}=7.1 \mathrm{~Hz}), 7.55(\mathrm{~m}, 2 \mathrm{H}), 7.16(\mathrm{dd}, 0.14 \mathrm{H}(Z), \mathrm{J}=9.1,6.6$ $\mathrm{Hz}), 5.75(\mathrm{dt}, 0.14 \mathrm{H}(Z), \mathrm{J}=49.1,6.4 \mathrm{~Hz}), 5.04(\mathrm{dt}, 0.58 \mathrm{H}(E), \mathrm{J}=48.2,6.9 \mathrm{~Hz}), 4.57(\mathrm{~s}, 2 \mathrm{H}), 4.47$ $(\mathrm{t}, 2 \mathrm{H}, \mathrm{J}=5.3 \mathrm{~Hz}), 4.43-4.38(\mathrm{~m}, 0.28 \mathrm{H}$ (cyclic)), 4.14-4.18 (m, 0.28H (cyclic)), 4.04-3.92 (m, 1H), 3.63-3.56 (m, 1H), 3.54-3.45 (m, 1H), 3.45-3.31 (m, 2H). ${ }^{13} \mathrm{C}-\mathrm{NMR}$ (300 MHz, DMSO) $\delta: 168.64$, 165.40, 158.08, 148.93 (E), 148.64 (Z), 144.63, 130.32, 127.96, 127.73, 91.83, 89.57, 78.21 (cyclic), 
72.65, 70.98, 70.19 (cyclic), 69.96 ( $E \& Z$ ), 69.67 (cyclic), $69.63(E), 69.58(Z), 63.20(E \& Z), 60.84$ (cyclic), 41.53.

\section{Synthesis of reference compound $\mathbf{1 2}$}

Compound 5 (16 mg, $40.8 \mu \mathrm{mol}, 1 \mathrm{eq})$ and 2-deoxy-2-fluoro-D-glucose (10) (74.3 mg, $407.9 \mu \mathrm{mol}$, 10 eq) were dissolved in $1 \mathrm{ml}$ of water. The mixture was kept at r.t. for 3 hours. The product was purified with HPLC. Separation was carried out on a Grace Alltima C18 column $(5 \mu \mathrm{m}, 250 \mathrm{~mm} \times$

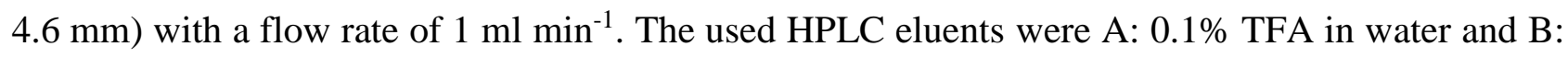
$0.1 \%$ TFA in acetonitrile. The gradient was 5 to $50 \% \mathrm{~B}$ (0-15 min). Retention time was 6.2 min (cyclic), $6.5 \mathrm{~min}(E)$, and $6.7 \mathrm{~min}(Z)$. After solvent removal by lyophilization the end product 12 was isolated as white powder (16.5 mg, $29.6 \mu \mathrm{mol}$, yield 72.7\%, purity 99\% (HPLC $209 \mathrm{~nm})$ ). Three product peaks were observed with HPLC. The peaks were collected and subjected to TOF-ESI-MS. MS analysis confirmed identical mass for all peaks. The peaks belong to the acyclic $E$ - and $Z$-isomers, and the cyclic pyranose isomer. Previous studies have also reported the formation of different isomers with hexose conjugates $[14,17,18,39]$.

TOF-ESI-MS $[\mathrm{M}+\mathrm{Na}]^{+} \mathrm{m} / z$ calcd. 579.1920 for $\mathrm{C}_{20} \mathrm{H}_{33} \mathrm{FN}_{4} \mathrm{O}_{13} \mathrm{Na}$, found 579.1921. ${ }^{1} \mathrm{H}-\mathrm{NMR}(300$ $\left.\mathrm{MHz}, \mathrm{D}_{2} \mathrm{O}\right) \delta: 7.80(\mathrm{dd}, 0.73 \mathrm{H}(E), \mathrm{J}=9.1,6.2 \mathrm{~Hz}), 7.21(\mathrm{dd}, 0.15 \mathrm{H}(Z), \mathrm{J}=10.4,5.9 \mathrm{~Hz}), 5.87$ (dt, $0.15 \mathrm{H}(Z), \mathrm{J}=48.0,5.6 \mathrm{~Hz}), 5.26(\mathrm{dt}, 0.73 \mathrm{H}(E), \mathrm{J}=47.4,6.5 \mathrm{~Hz}), 4.66(\mathrm{~s}, 0.3 \mathrm{H}(Z)), 4.65(\mathrm{~s}, 1.46 \mathrm{H}$ (E)), 4.36-4.28 (m, 2H), 4.28-4.16 (m, 2H), 4.00-3.76 (m, 2H), 3.74-3.63 (m, 2H), 3.59-3.43 (m, 1H), $3.30(\mathrm{t}, 2 \mathrm{H}, \mathrm{J}=6.7 \mathrm{~Hz}), 2.56(\mathrm{t}, 2 \mathrm{H}, \mathrm{J}=7.3 \mathrm{~Hz}), 2.29-2.14(\mathrm{~m}, 1 \mathrm{H}), 2.09-1.94(\mathrm{~m}, 1 \mathrm{H}), 1.94-1.81(\mathrm{~m}$, 1H), $1.81-1.68(\mathrm{~m}, 1 \mathrm{H}), 1.68-1.52(\mathrm{~m}, 2 \mathrm{H}), 1.52-1.36(\mathrm{~m}, 2 \mathrm{H}) .{ }^{13} \mathrm{C}-\mathrm{NMR}\left(300 \mathrm{MHz}, \mathrm{D}_{2} \mathrm{O}\right) \delta: 177.66$, 177.53, 176.66, 172.11, 159.72, $150.03(E), 149.74(Z), 91.96,89.68,77.87$ (cyclic), $72.63(E), 72.32$ (Z), 71.65 (cyclic), 71.06, 70.42 (cyclic), 70.10 ( $E \& Z$ Z), 69.72 (cyclic), $69.60(E), 69.48(Z), 63.20$ (E\& Z), 60.84 (cyclic), 53.58, 52.97, 39.09, 30.94, 30.45, 28.19, 26.63, 22.62.

\section{$\left[{ }^{18} \mathrm{~F}\right] \mathrm{FDR}$ synthesis $\left(\left[{ }^{18} \mathrm{~F}\right] 3\right)$}


$\left[{ }^{18} \mathrm{~F}^{-} \mathrm{F}^{-}\right.$was trapped on a Sep-Pak QMA Light anion-exchange cartridge (Waters, preconditioned with $10 \mathrm{ml}$ of $0.5 \mathrm{M} \mathrm{K}_{2} \mathrm{CO}_{3}$ and $15 \mathrm{ml}$ of water) and eluted as a ${ }^{18} \mathrm{~F}^{-} / \mathrm{Kryptofix} 2.2 .2 / \mathrm{K}^{+}$complex to a conical reaction vial (Grace Davison Discovery Sciences, Deerfield, IL, USA). The ${ }^{18} \mathrm{~F}^{-} /$Kryptofix $2.2 .2 / \mathrm{K}^{+}$complex was dried with azeotropic distillation at $120{ }^{\circ} \mathrm{C}$ under an $\mathrm{Ar}$ flow $(40 \mathrm{ml} \mathrm{min}-1)$ and cooled to r.t. Precursor $1(5 \mathrm{mg}, 14.0 \mu \mathrm{mol})$ in $500 \mu \mathrm{l}$ of DNA-synthesis grade anhydrous acetonitrile (Merck) was added in to the reaction vial. The reaction mixture was heated to $108{ }^{\circ} \mathrm{C}$ for $12 \mathrm{~min}$, and then cooled to r.t. DMT-Cl $(24 \mathrm{mg}, 70.8 \mu \mathrm{mol}, 5 \mathrm{eq})$ in pyridine $(0.5 \mathrm{ml})$ was added and the reaction was let to stand for $5 \mathrm{~min}$. The mixture was transferred with gas flow to a vial with $30 \mathrm{ml}$ of water, and $0.5 \mathrm{ml}$ of $6 \mathrm{M} \mathrm{HCl}$ to neutralize the pyridine. The mixture was passed through two C18 Sep-Pak cartridges (preconditioned with $5 \mathrm{ml}$ of ethanol and $10 \mathrm{ml}$ of water). The C18 cartridges were rinsed with $15 \mathrm{ml}$ of water. $\left[{ }^{18} \mathrm{~F}\right] 2$ was eluted out with $4 \mathrm{ml}$ of $50 \%$ acetonitrile into a $5 \mathrm{ml}$ septum-sealed reaction vial, which was loaded with $400 \mu \mathrm{l}$ of $6 \mathrm{M} \mathrm{HCl}$. The reaction vial was heated to $110{ }^{\circ} \mathrm{C}$ for $10 \mathrm{~min}$ and cooled down to r.t. For neutralization $390 \mu \mathrm{l}$ of $6 \mathrm{M} \mathrm{NaOH}$ was added. The solution was concentrated with Ar gas flow $\left(90 \mathrm{ml} \mathrm{min}{ }^{-1}\right)$ under heating at $110{ }^{\circ} \mathrm{C}$ to 1 $\mathrm{ml}$.

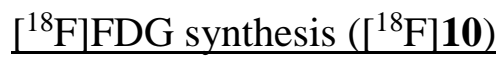

$\left[{ }^{18} \mathrm{~F}^{-} \mathrm{F}^{-}\right.$was trapped on a Sep-Pak QMA Light anion-exchange cartridge (Waters, preconditioned with $10 \mathrm{ml}$ of $0.5 \mathrm{M} \mathrm{K}_{2} \mathrm{CO}_{3}$ and $15 \mathrm{ml}$ of water) and eluted as a ${ }^{18} \mathrm{~F}^{-} / \mathrm{Kryptofix} 2.2 .2 / \mathrm{K}^{+}$complex to a conical reaction vial (Grace Davison Discovery Sciences, Deerfield, IL, USA). The ${ }^{18} \mathrm{~F}^{-} /$Kryptofix 2.2.2/ $\mathrm{K}^{+}$complex was dried with azeotropic distillation at $120{ }^{\circ} \mathrm{C}$ under an $\mathrm{Ar}$ flow $\left(40 \mathrm{ml} \mathrm{min} \mathrm{m}^{-1}\right)$ and cooled to r.t. Precursor $8(25 \mathrm{mg}, 52.0 \mu \mathrm{mol})$ in $500 \mu \mathrm{l}$ of DNA-synthesis grade anhydrous acetonitrile (Merck) was added in to the reaction vial. The reaction mixture was heated to $85{ }^{\circ} \mathrm{C}$ for $5 \mathrm{~min}$, and then cooled to r.t. DMT-Cl $(88 \mathrm{mg}, 259.7 \mu \mathrm{mol}, 5 \mathrm{eq})$ in pyridine $(0.5 \mathrm{ml})$ was added and the reaction was let to stand for $5 \mathrm{~min}$. The mixture was transferred with gas flow to a vial with $30 \mathrm{ml}$ of water, and $0.5 \mathrm{ml}$ of $6 \mathrm{M} \mathrm{HCl}$ to neutralize the pyridine. The mixture was passed through 
C18 Light Sep-Pak cartridge (preconditioned with $5 \mathrm{ml}$ of ethanol and $10 \mathrm{ml}$ of water). The C18 Light Sep-Pak cartridge was rinsed with $15 \mathrm{ml}$ of water. The removal of protective groups was done on cartridge by eluting the cartridge first with $2 \times 0.5 \mathrm{ml}$ of $1 \mathrm{M} \mathrm{NaOH}$ and then with $1 \mathrm{ml}$ of water into a vial with $166 \mu \mathrm{l}$ of $6 \mathrm{M} \mathrm{HCl}$. For final purification, the solution was passed through a C18 Light Sep-Pak cartridge (preconditioned with $5 \mathrm{ml}$ of ethanol and $10 \mathrm{ml}$ of water) and an Alumina N SepPak cartridge (preconditioned with $50 \mathrm{ml}$ water). The cartridges were rinsed with $1 \mathrm{ml}$ of water.

\section{$\underline{\text { Oxime formation between }\left[{ }^{18} \mathrm{~F}\right] 3\left(\left[{ }^{18} \mathrm{~F}\right] \mathrm{FDR}\right) \text { and precursor } 4 \text { to yield }\left[{ }^{18} \mathrm{~F}\right] 6}$}

The aminooxy precursor $4(0.33 \mathrm{mg}, 1.27 \mu \mathrm{mol}), 1 \mathrm{ml}$ of $\left[{ }^{18} \mathrm{~F}\right] \mathbf{3}$, and anilinium acetate buffer $(330 \mu 1$, 1.2M, $\mathrm{pH} 4.6$ ) were mixed. The reaction was kept at r.t. for $1 \mathrm{~min}$. The reaction mixture was passed through AminoLink resin ( $1 \mathrm{ml}$ slurry $(0.5 \mathrm{ml}$ of resin), preconditioned with $6 \mathrm{ml}$ of water), and the resin was rinsed with $1 \mathrm{ml}$ of acetonitrile. The mixture was diluted with $20 \mathrm{ml}$ of $10 \mathrm{mM} \mathrm{HCl}$ and passed through a C18 Sep-Pak cartridge (preconditioned with $5 \mathrm{ml}$ of ethanol and $10 \mathrm{ml}$ of water). The cartridge was washed with $20 \mathrm{ml}$ of $10 \mathrm{mM} \mathrm{HCl}$ and $2 \mathrm{ml}$ of water. The product was eluted with $1.5 \mathrm{ml}$ of $50 \%$ ethanol.

\section{Oxime formation between $\left[{ }^{18} \mathrm{~F}\right] \mathbf{3}\left(\left[{ }^{18} \mathrm{~F}\right] \mathrm{FDR}\right)$ and precursor 5 to yield $\left[{ }^{18} \mathrm{~F}\right] \mathbf{7}$}

The aminooxy precursor $5(0.5 \mathrm{mg}, 1.27 \mu \mathrm{mol}), 1 \mathrm{ml}$ of $\left[{ }^{18} \mathrm{~F}\right] \mathbf{3}$, and anilinium acetate buffer $(330 \mu 1$, 1.2M, $\mathrm{pH}$ 4.6) were mixed. The reaction was kept at r.t. for $1 \mathrm{~min}$. The mixture was diluted with 10 $\mathrm{ml}$ of $10 \mathrm{mM} \mathrm{HCl}$ and passed through a C18 Sep-Pak cartridge (preconditioned with $5 \mathrm{ml}$ of ethanol and $10 \mathrm{ml}$ of water). The cartridge was washed with $20 \mathrm{ml}$ of $10 \mathrm{mM} \mathrm{HCl}$ and $2 \mathrm{ml}$ of water. The product was eluted with $1.5 \mathrm{ml}$ of $50 \%$ ethanol. The reaction mixture was passed through AminoLink resin ( $1 \mathrm{ml}$ slurry $(0.5 \mathrm{ml}$ of resin), preconditioned with $6 \mathrm{ml}$ water $)$, and the resin was rinsed with 1 $\mathrm{ml}$ of water.

$\underline{\text { Oxime formation between }\left[{ }^{18} \mathrm{~F}\right] \mathbf{1 0}\left(\left[{ }^{18} \mathrm{~F}\right] \mathrm{FDG}\right) \text { and precursor } \mathbf{4} \text { to yield }\left[{ }^{18} \mathrm{~F}\right] \mathbf{1 1}}$ 
The aminooxy tetrazine precursor $4(0.33 \mathrm{mg}, 1.27 \mu \mathrm{mol}), 1 \mathrm{ml}$ of $\left[{ }^{18} \mathrm{~F}\right] \mathbf{1 0}$, and anilinium acetate buffer $(330 \mu 1,1.2 \mathrm{M}, \mathrm{pH} 4.6)$ were mixed. The reaction mixture was kept at $60{ }^{\circ} \mathrm{C}$ for $5 \mathrm{~min}$. After the oxime formation, the reaction mixture was passed through AminoLink resin $(1 \mathrm{ml}$ slurry $(0.5 \mathrm{ml}$ of resin), preconditioned with $6 \mathrm{ml}$ water), and the resin was rinsed with $1 \mathrm{ml}$ of acetonitrile. The mixture was diluted with $20 \mathrm{ml}$ of $10 \mathrm{mM} \mathrm{HCl}$ and passed through a C18 Sep-Pak cartridge (preconditioned with $5 \mathrm{ml}$ of ethanol and $10 \mathrm{ml}$ of water). The cartridge was washed with $20 \mathrm{ml}$ of $10 \mathrm{mM} \mathrm{HCl}$ and $2 \mathrm{ml}$ of water. The product was eluted with $1.5 \mathrm{ml}$ of $50 \%$ ethanol.

\section{$\underline{\text { Oxime formation between }\left[{ }^{18} \mathrm{~F}\right] \mathbf{1 0}\left(\left[{ }^{18} \mathrm{~F}\right] \mathrm{FDG}\right) \text { and precursor } \mathbf{5} \text { to yield }\left[{ }^{18} \mathrm{~F}\right] \mathbf{1 2}}$}

The aminooxy precursor $5(0.5 \mathrm{mg}, 1.27 \mu \mathrm{mol}), 1 \mathrm{ml}$ of $\left[{ }^{18} \mathrm{~F}\right] \mathbf{1 0}$, and anilinium acetate buffer $(330 \mu 1$, 1.2M, $\mathrm{pH} 4$ 4) were mixed. The reaction mixture was kept at $85{ }^{\circ} \mathrm{C}$ for $30 \mathrm{~min}$. After the oxime formation, the mixture was diluted with $10 \mathrm{ml}$ of $10 \mathrm{mM} \mathrm{HCl}$ and passed through a $\mathrm{C} 18 \mathrm{Sep}-\mathrm{Pak}$ cartridge (preconditioned with $5 \mathrm{ml}$ of ethanol and $10 \mathrm{ml}$ of water). The cartridge was washed with $20 \mathrm{ml}$ of $10 \mathrm{mM} \mathrm{HCl}$ and $2 \mathrm{ml}$ of water. The product was eluted with $1.5 \mathrm{ml}$ of $50 \%$ ethanol. The reaction mixture was passed through AminoLink resin ( $1 \mathrm{ml}$ slurry ( $0.5 \mathrm{ml}$ of resin), preconditioned with $6 \mathrm{ml}$ water), and the resin was rinsed with $1 \mathrm{ml}$ of water.

\section{$\underline{\text { Results }}$}

We used ${ }^{18} \mathrm{~F}$-fluoroglycosylation via oxime formation to radiolabel an aminooxy functionalized tetrazine derivative and a PSMA inhibitor with $\left[{ }^{18} \mathrm{~F}\right] \mathrm{FDR}$ and $\left[{ }^{18} \mathrm{~F}\right] \mathrm{FDG}$ (Scheme 1). The focus of the work was to develop HPLC-free purification methods to decrease the synthesis time and facilitate future automation of ${ }^{18} \mathrm{~F}$-fluoroglycosylation radiosynthesis. Excess unreacted carbohydrate precursor was derivatized with 4,4'-dimethoxytrityl chloride (DMT-Cl), thus increasing the lipophilicity of the unreacted precursor and enabling its separation from the fluorinated precursor with reverse-phase C18 Sep-Pak cartridge. The aminooxy precursor was trapped on an aldehyde resin 
(AminoLink), and $\left[{ }^{18} \mathrm{~F}\right] \mathrm{FDR}$ or $\left[{ }^{18} \mathrm{~F}\right] \mathrm{FDG}$ was separated from the ${ }^{18} \mathrm{~F}$-fluoroglycoconjugate end product with $\mathrm{C} 18$ Sep-Pak cartridge.

\section{$\left[{ }^{18} \mathrm{~F}\right] \mathrm{FDR}$ synthesis $\left(\left[{ }^{18} \mathrm{~F}\right] \mathbf{3}\right)$}

Fig. 2 represents the HPLC chromatograms after each step in the synthesis of the ribose precursor $\left[{ }^{18} \mathrm{~F}\right] \mathrm{FDR}\left(\left[{ }^{18} \mathrm{~F}\right] \mathbf{3}\right)$. After the reaction with DMT-Cl, we did not observe the carbohydrate precursor $\mathbf{1}$ with HPLC. After the C18 cartridge purification and deprotection, the RCP (radiochemical purity) and decay corrected yield of $\left[{ }^{18} \mathrm{~F}\right] 3$, when starting from ${ }^{18} \mathrm{~F}^{-}, 500-2000 \mathrm{MBq}$ at EOS (end of synthesis), were $>99 \%$ and $80 \pm 5 \%$, respectively $(n=12)$. The total synthesis time was typically 85 min starting from ${ }^{18} \mathrm{~F}^{-}$.

\section{$\left[{ }^{18} \mathrm{~F}\right] \mathrm{FDG}$ synthesis $\left(\left[{ }^{18} \mathrm{~F}\right] \mathbf{1 0}\right)$}

Fig. 3 represents the HPLC chromatograms after each step in the synthesis of the $\left[{ }^{18} \mathrm{~F}\right] \mathrm{FDG}\left(\left[{ }^{18} \mathrm{~F}\right] \mathbf{1 0}\right)$ radiolabeling precursor. After the reaction with $\mathrm{DMT}-\mathrm{Cl}$, the carbohydrate precursor $\mathbf{8}$ was not detected with HPLC. After the C18 cartridge purification and deprotection, the RCP and decay corrected yield of $\left[{ }^{18} \mathrm{~F}\right] \mathrm{FDG}$, starting from ${ }^{18} \mathrm{~F}^{-}, 500-1500 \mathrm{MBq}$ at EOS, were $>99 \%$ and $65 \pm 7 \%$, respectively $(n=12)$. The total synthesis time was typically 45 min starting from ${ }^{18} \mathrm{~F}^{-}$.

\section{$\left[{ }^{18} \mathrm{~F}\right] \mathrm{FDR}$-tetrazine $\left(\left[{ }^{18} \mathrm{~F}\right] \mathbf{6}\right)$}

Samples were taken at $1 \mathrm{~min}, 5 \mathrm{~min}, 10 \mathrm{~min}, 20 \mathrm{~min}$, and $30 \mathrm{~min}$ to follow the reaction between $\left[{ }^{18} \mathrm{~F}\right] 3$ and precursor 4 with radio-TLC. The oxime formation proceeded to near completion in one minute at r.t. and the end product remained stable over the whole observation period of 30 minutes (Fig. 4 A). Based on the results, reaction time of 1 min was chosen to be used in further studies. After the AminoLink and C18 cartridge purification, the RCP, decay-corrected yield (starting from ${ }^{18} \mathrm{~F}^{-}, 300$ $700 \mathrm{MBq}$ at EOS), and molar activity for $\left[{ }^{18} \mathrm{~F}\right] 6$ were $>99 \%, 73 \pm 7 \%$ and $>800 \mathrm{GBq}^{\mathrm{mmol}}{ }^{-1}$, respectively $(n=3)$. Fig. 5 represents the HPLC chromatograms of the $\left[{ }^{18}\right.$ F $]$ FDR-tetrazine conjugate $\left[{ }^{18} \mathrm{~F}\right] \mathbf{6}$ before and after purification. The amount of the residual aminooxy precursor was below LOD 
(limit of detection, $<0.1 \mathrm{nmol}$ ). The total synthesis time was typically $95 \mathrm{~min}$ (starting from ${ }^{18} \mathrm{~F}^{-}$).

Table 1 represents comparison of these results to previously used HPLC-purification method [35].

\section{$\left[{ }^{18} \mathrm{~F}\right]$ FDR-PSMA inhibitor $\left(\left[{ }^{18} \mathrm{~F}\right] 7\right)$}

Samples were taken at $1 \mathrm{~min}, 5 \mathrm{~min}, 10 \mathrm{~min}, 20 \mathrm{~min}$, and $30 \mathrm{~min}$ to follow the reaction between $\left[{ }^{18} \mathrm{~F}\right] \mathbf{3}$ and 5 with radio-TLC. The oxime reaction proceeded to nearly completion in one minute at r.t. and the end product remained stable over the whole observation period of 30 minutes (Fig. 4 B). Reaction time of 1 min was chosen to be used in further studies. After the AminoLink and C18 cartridge purifications, the RCP, decay-corrected yield (starting from ${ }^{18} \mathrm{~F}^{-}, 250-700 \mathrm{MBq}$ at EOS), and molar activity for $\left[{ }^{18} \mathrm{~F}\right] 7$ were $>99 \%, 75 \pm 6 \%$ and $>600 \mathrm{GBq} \mu \mathrm{mol}^{-1}$, respectively $(\mathrm{n}=3)$. The amount of the residual aminooxy precursor was below LOD $(<0.1 \mathrm{nmol})$. The total synthesis time was typically 95 min (starting from ${ }^{18} \mathrm{~F}^{-}$).

\section{$\left[{ }^{18} \mathrm{~F}\right] \mathrm{FDG}-$ tetrazine $\left(\left[{ }^{18} \mathrm{~F}\right] \mathbf{1 1}\right)$}

In order to find the optimal reaction conditions for the conjugation between $\left[{ }^{18} \mathrm{~F}\right] \mathbf{1 0}$ and $\mathbf{4}$, the reaction mixture was kept at r.t. $(n=2)$, or heated to $60{ }^{\circ} \mathrm{C}(\mathrm{n}=3)$ or $85^{\circ} \mathrm{C}(\mathrm{n}=3)$. Samples were taken at 1 $\mathrm{min}, 5 \mathrm{~min}, 10 \mathrm{~min}, 20 \mathrm{~min}$, and $30 \mathrm{~min}$ to follow the reaction progress with radio-TLC. The highest conjugation yields were observed 5 minutes after reaction start when heating was applied: $61.3 \pm 3.5 \%$ $\left(60{ }^{\circ} \mathrm{C}, \mathrm{n}=3\right)$, and $31.6 \pm 1.6 \%\left(85^{\circ} \mathrm{C}, \mathrm{n}=3\right)$ (Fig. $\left.4 \mathrm{~A}\right)$. Reaction time of $5 \mathrm{~min}$ and temperature of $60{ }^{\circ} \mathrm{C}$ were chosen to be used in further studies. After the AminoLink and $\mathrm{C} 18$ cartridge purifications, the RCP, decay-corrected yield (starting from ${ }^{18} \mathrm{~F}^{-}, 200-500 \mathrm{MBq}$ at EOS), and molar activity for $\left[{ }^{18} \mathrm{~F}\right] \mathbf{1 1}$ were $>99 \%, 35 \pm 4 \%$ and $>800 \mathrm{GBq} \mu \mathrm{mol}^{-1}$, respectively $(\mathrm{n}=4)$. The amount of the residual aminooxy precursor was below LOD $(<0.1 \mathrm{nmol})$. The total synthesis time was typically $60 \mathrm{~min}$ (starting from ${ }^{18} \mathrm{~F}^{-}$, oxime formation: 5 min at $60{ }^{\circ} \mathrm{C}$ ).

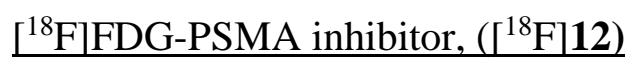


In order to determine the optimal reaction conditions for the conjugation between $\left[{ }^{18} \mathrm{~F}\right] \mathbf{1 0}$ and $\mathbf{5}$, the reaction mixture was kept at r.t. $(n=2)$, or heated to $60{ }^{\circ} \mathrm{C}(\mathrm{n}=3)$ or $85{ }^{\circ} \mathrm{C}(\mathrm{n}=3)$. Samples were taken at $1 \mathrm{~min}, 5 \mathrm{~min}, 10 \mathrm{~min}, 20 \mathrm{~min}$, and $30 \mathrm{~min}$ to follow the reaction progress with radio-TLC. The highest conjugation yields were observed 30 minutes after the start of the reaction. The reaction was facilitated by increased temperature: $12.9 \pm 1.2 \%($ r.t., $\mathrm{n}=2), 36.3 \pm 0.5 \%\left(60{ }^{\circ} \mathrm{C}, \mathrm{n}=3\right.$ ), and $90.4 \pm 1.6 \%\left(85^{\circ} \mathrm{C}, \mathrm{n}=3\right.$ ) (Fig. 4 B). Reaction time of $30 \mathrm{~min}$ and temperature of $85^{\circ} \mathrm{C}$ were chosen to be used in further studies. After the AminoLink and C18 cartridge purifications, the RCP, decaycorrected yield (starting from ${ }^{18} \mathrm{~F}^{-}, 300-650 \mathrm{MBq}$ at EOS), and molar activity for $\left[{ }^{18} \mathrm{~F}\right] \mathbf{1 2}$ were $>99 \%$, $54 \pm 6 \%$ and $>600 \mathrm{GBq} \mu \mathrm{mol}^{-1}$, respectively $(\mathrm{n}=4)$. Fig. 5 represents the HPLC chromatograms of $\left[{ }^{18} \mathrm{~F}\right] \mathbf{1 2}$ before and after purification. The amount of the residual aminooxy precursor was below LOD $(<0.1 \mathrm{nmol})$. The total synthesis time was typically $85 \mathrm{~min}$ (starting from ${ }^{18} \mathrm{~F}^{-}$, oxime formation: 30 $\min$ at $\left.85^{\circ} \mathrm{C}\right)$.

\section{$\underline{\text { Residuals of aniline and pyridine }}$}

Extra precautions should be taken to ensure that there are not residues of either aniline and pyridine present in the end products, since both compounds are toxic and carcinogenic. Before the last $\mathrm{C} 18$ Sep-Pak cartridge purification, the reaction mixture was diluted with $10 \mathrm{mM} \mathrm{HCl}(\mathrm{pH} 2)$ and the cartridge was washed with excess of $10 \mathrm{mM} \mathrm{HCl}$. In these conditions both compounds, aniline $\left(\mathrm{pK}_{\mathrm{a}}\right.$ of conjugate acid: 4.6) and pyridine ( $\mathrm{pK}_{\mathrm{a}}$ of conjugate acid: 5.25), are ionized and not retained on $\mathrm{C} 18$ cartridge. We did not detect any residual peaks of aniline and pyridine when the non-diluted end products $(100 \mu \mathrm{l})$ were injected to the HPLC. The limit of detection (LOD) with our HPLC method was $54 \mathrm{pmol}$ and $253 \mathrm{pmol}$ for aniline and pyridine, respectively. Based on these LODs, the end products would contain $<0.8 \mathrm{nmol}$ and $<3.8 \mathrm{nmol}$ of aniline and pyridine, respectively.

\section{$\underline{\text { Discussion }}$}


A typical synthesis procedure for ${ }^{18} \mathrm{~F}$-fluoroglycosylation with $\left[{ }^{18} \mathrm{~F}\right] \mathrm{FDR}$ and $\left[{ }^{18} \mathrm{~F}\right] \mathrm{FDG}$ involves two HPLC purifications. In this study, we have developed an efficient cartridge purification method to replace both of the HPLC purification steps. If the carbohydrate precursor is not removed after the fluorination step during the radiosynthesis of $\left[{ }^{18} \mathrm{~F}\right] \mathrm{FDR}$ and $\left[{ }^{18} \mathrm{~F}\right] \mathrm{FDG}$, it will get deprotected and hydrolyzed in the next steps, leading to an end product that contains ribose (FDR synthesis) or glucose (FDG synthesis) that will compete in the subsequent oxime formation reaction. Therefore, the $\left[{ }^{18} \mathrm{~F}\right] \mathrm{FDR}$ and $\left[{ }^{18} \mathrm{~F}\right] \mathrm{FDG}$ are usually purified with HPLC before the oxime formation, or the end product is separated from glucose/ribose conjugate with HPLC after the oxime formation. Here, we present a way to circumvent the HPLC purification by adding one step, the derivatization of the carbohydrate precursor with DMT-Cl, to the radiosynthesis of $\left[{ }^{18} \mathrm{~F}\right] \mathrm{FDR}$ and $\left[{ }^{18} \mathrm{~F}\right] \mathrm{FDG}$. Conjugation of the DMT moiety increased the lipophilicity of the carbohydrate precursor and enables its separation from the fluorinated carbohydrate precursor with C18 Sep-Pak cartridge before the deprotection step. The addition of the DMT-Cl to the reaction vial after the fluorination reaction proved to be very efficient, since no carbohydrate precursor could be detected with HPLC. A facile C18 Sep-Pak SPE purification retained the DMT-carbohydrate precursor complex entirely and the following oxime formation reaction proceeded in high yields with a low concentration of aminooxy precursor $(\sim 1$ $\mathrm{mM})$.

To replace the second HPLC purification for the removal of the unreacted aminooxy precursor, we used an aldehyde resin (AminoLink) which quantitatively trapped the precursor. In addition to $\left[{ }^{18} \mathrm{~F}\right] \mathrm{FDR}$ and $\left[{ }^{18} \mathrm{~F}\right] \mathrm{FDG}$ other ${ }^{18} \mathrm{~F}$-labeled aldehydes, such as $4-\left[{ }^{18} \mathrm{~F}\right]$ fluorobenzaldehyde, have been used to radiolabel aminooxy-functionalized molecules [40-46]. The AminoLink purification method developed in the present work could be a valuable tool for these applications as well. The developed method enables the HPLC-free separation of the oxime end product from the aminooxy precursor, and the production of high apparent molar activity oxime end products in cases where it has been 
impossible to separate the aminooxy precursor from the oxime end product with liquid chromatography due to the very similar retention properties of the two compounds.

Earlier, we have reported the synthesis of the $\left[{ }^{18} \mathrm{~F}\right] \mathrm{FDR}$-conjugated tetrazine $\left[{ }^{18} \mathrm{~F}\right] \mathbf{6}$ using a method requiring two HPLC purifications [35, 47, 48]. With the HPLC purifications, the radiochemical purity

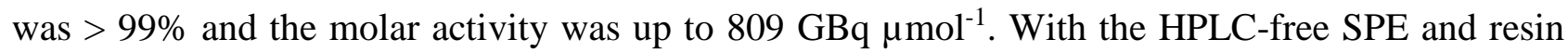
method reported here, we achieved the same radiochemical purity and molar activity levels (> 800 $\left.\mathrm{GBq} \mu \mathrm{mol}^{-1}\right)$. The total radiosynthesis time, however, was decreased by 25 minutes $(95$ min versus $120 \mathrm{~min}$ ), and the simplified purification procedures are extremely useful towards the automation of ${ }^{18}$ F-fluoroglycosylation synthesis via oxime formation.

In the present study, both tetrazine and PSMA inhibitor aminooxy precursors conjugated rapidly with $\left[{ }^{18} \mathrm{~F}\right] \mathrm{FDR}$ at room temperature with aniline as a catalyst. With $\left[{ }^{18} \mathrm{~F}\right] \mathrm{FDG}$ heating of the reaction was required as expected. $\left[{ }^{18} \mathrm{~F}\right] \mathrm{FDG}$ has been used in the ${ }^{18} \mathrm{~F}$-fluoroglycosylation of a variety of molecules, always with heating $[1-3,7,9,14-16,18]$. The $\left[{ }^{18} \mathrm{~F}\right] \mathrm{FDG}$ conjugation also required longer reaction times than the $\left[{ }^{18} \mathrm{~F}\right] \mathrm{FDR}$ conjugation: for the PSMA inhibitor, for example, 30 min with $\left[{ }^{18} \mathrm{~F}\right] \mathrm{FDG}$ was required compared to the 1 min with $\left[{ }^{18} \mathrm{~F}\right] \mathrm{FDR}$.

Our results corroborate that the milder conditions of the $\left[{ }^{18} \mathrm{~F}\right] \mathrm{FDR}$ fluoroglycosylation are more suitable for heat-sensitive molecules, such as tetrazines. The aminooxy tetrazine 4 could be conjugated with $\left[{ }^{18} \mathrm{~F}\right] \mathrm{FDR}$ at radiochemical yields exceeding $95 \%$, but with $\left[{ }^{18} \mathrm{~F}\right] \mathrm{FDG}$ the highest yields achieved were around $60 \%$. The yields of the $\left[{ }^{18} \mathrm{~F}\right] \mathrm{FDG}$-tetrazine $\left(\left[{ }^{18} \mathrm{~F}\right] \mathbf{1 1}\right)$ conjugation reaction started dropping after the first 10 minutes when heating was applied, and a temperature of $85{ }^{\circ} \mathrm{C}$ resulted in lower yields than $60{ }^{\circ} \mathrm{C}$. This might be due to the degradation of the tetrazine moiety upon heating. Tetrazines are known to decompose at high temperatures and at basic conditions. For this reason their direct fluorination usually fails or has poor yields. The tetrazine structure could be stabilized by using electron donating groups as substituents [49]. For example Rashidian et al. have successfully radiolabeled a methyl tetrazine derivative with $\left[{ }^{18} \mathrm{~F}\right] \mathrm{FDG}$ with high yield, when using $p$ - 
phenylenediamine as catalyst [15]. The reaction at $70-75{ }^{\circ} \mathrm{C}$ for $5-10 \mathrm{~min}$ provided the $\left[{ }^{18} \mathrm{~F}\right] \mathrm{FDG}$ conjugate with $>90 \%$ RCY. Concentration of the aminooxy precursor has also a significant role in the yield of the oxime formation. The radiolabeling of the methyl tetrazine in the work of Rashidian et al. was carried out in $\sim 0.2-0.3 \mathrm{M}$ range of aminooxy precursor, whereas our reaction was in $\sim 1$ $\mathrm{mM}$ of the aminooxy precursor.

The oxime end products $\mathbf{6 , 7 , 1 1}$, and $\mathbf{1 2}$ have an imine double bond and occur in $E$ and $Z$ isomers in solution. The $E / Z$ isomeric ratio depends on the size of the substitutes on the double bond. With the FDR-conjugated compounds no cyclic form was detected. In contrast, with the FDG conjugated compounds the formation of the cyclic isomer was observed with both HPLC and NMR. These findings are in accordance with previous studies with FDR and FDG glycoconjugates [14, 17, 18, 20, $23,35,39]$. Because the different isomers equilibrate quickly in solution, they are not usually isolated from each other and are considered as one compound. Reduction of the imine double bond would lead to single isomer. However, the reduction might take too long with respect to the physical halflife of fluorine-18 (109.8 $\mathrm{min}$ ), and at least in the case of FDG, the yield would not be quantitative due to the presence of the cyclic form, the removal of which would require an additional purification step [39].

The hydroxyl groups in both $\left[{ }^{18} \mathrm{~F}\right] \mathrm{FDR}$ and $\left[{ }^{18} \mathrm{~F}\right] \mathrm{FDG}$ lower the lipophilicity of the oxime end product. This is often desired since low lipophilicity usually favors rapid urinary elimination of the radiolabeled tracer. Glycosylation of small radiolabeled peptides has in fact been shown to reduce their hepatobiliary excretion [29-31, 50]. The aminooxy functional group can be attached to almost any molecule and the radiolabeling can be carried out under mild reaction conditions using a carbohydrate prosthetic group. Consequently ${ }^{18} \mathrm{~F}$-fluoroglycosylation is a handy tool for fluorine-18 radiolabeling of various molecules that cannot tolerate the harsh reaction conditions of direct nucleophilic fluorination. The versatility, mild conditions, and chemoselectivity of glycoconjugation are the most appealing features prompting the use of carbohydrate prosthetic groups for radiolabeling. 
With the present work, the feasibility of applying this highly versatile radiosynthetic strategy for the automated production of ${ }^{18} \mathrm{~F}$-radiolabeled compounds is greatly advanced driving clinical translation of ${ }^{18} \mathrm{~F}$-fluoroglycosylated tracers.

\section{$\underline{\text { Conclusions }}$}

Herein, we report efficient cartridge purification method for ${ }^{18} \mathrm{~F}$-fluoroglycosylation via oxime formation. The carbohydrate precursors of $\left[{ }^{18} \mathrm{~F}\right] \mathrm{FDR}$ and $\left[{ }^{18} \mathrm{~F}\right] \mathrm{FDG}$ were efficiently removed before oxime formation, and the aminooxy precursors of the two model compounds were quantitatively trapped with an aldehyde resin. The oxime end products were obtained with high yield, radiochemical purity, and apparent molar activity. The developed purification method enables simpler and faster automated radiosynthesis of ${ }^{18} \mathrm{~F}$-glycoconjugates for clinical translation.

\section{Acknowledgements}

The authors gratefully thank Dr. Petri Heinonen and Eliza Lambidis for the ESI-MS measurements.

\section{$\underline{\text { References }}$}

[1] Al Jammaz I, Al-Otaibi B, AlHindas H, and Okarvi SM. Novel synthesis and initial preclinical evaluation of ${ }^{18} \mathrm{~F}$-[FDG] labeled rhodamine: a potential PET myocardial perfusion imaging agent. Nucl Med Biol 2015;42:804-8.

[2] Al Jammaz I, Al-Otaibi B, Amer S, Al-Hokbany N, and Okarvi S. Novel synthesis and preclinical evaluation of folic acid derivatives labeled with ${ }^{18} \mathrm{~F}$-[FDG] for PET imaging of folate receptor-positive tumors. Nucl Med Biol 2012;39:864-70.

[3] Bouvet V, Wuest M, Bailey JJ, Bergman C, Janzen N, Valliant JF, et al. Targeting ProstateSpecific Membrane Antigen (PSMA) with F-18-Labeled Compounds: the Influence of Prosthetic Groups on Tumor Uptake and Clearance Profile. Mol Imag Biol 2017;19:923-32. 
[4] Feni L, Omrane M, Fischer M, Zlatopolskiy B, Neumaier B, and Neundorf I. Convenient Preparation of ${ }^{18} \mathrm{~F}$-Labeled Peptide Probes for Potential Claudin-4 PET Imaging. Pharmaceuticals 2017;10:99.

[5] Fischer CR, Groehn V, Reber J, Schibli R, Ametamey SM, and Müller C. Improved PET Imaging of Tumors in Mice Using a Novel ${ }^{18} \mathrm{~F}$-Folate Conjugate with an Albumin-Binding Entity. Mol Imag Biol 2013;15:649-54.

[6] Fischer CR, Müller C, Reber J, Müller A, Krämer SD, Ametamey SM, et al. [ ${ }^{18}$ F]Fluoro-DeoxyGlucose Folate: A Novel PET Radiotracer with Improved in Vivo Properties for Folate Receptor Targeting. Bioconjugate Chem 2012;23:805-13.

[7] Frau S, Dall'Angelo S, Baillie GL, Ross RA, Pira M, Tseng C-C, et al. Pyrazole-type cannabinoid ligands conjugated with fluoro-deoxy-carbohydrates as potential PET-imaging agents: Synthesis and CB1/CB2 receptor affinity evaluation. J Fluor Chem 2013;152:166-72.

[8] Hofmann S, Maschauer S, Kuwert T, Beck-Sickinger AG, and Prante O. Synthesis and in Vitro and in Vivo Evaluation of an ${ }^{18} \mathrm{~F}$-Labeled Neuropeptide Y Analogue for Imaging of Breast Cancer by PET. Mol Pharm 2015;12:1121-30.

[9] Hultsch C, Schottelius M, Auernheimer J, Alke A, and Wester H-J. ${ }^{18}$ F-Fluoroglucosylation of peptides, exemplified on cyclo(RGDfK). Eur J Nucl Med Mol Imaging 2009;36:1469-74.

[10] Lang C, Maschauer S, Hübner H, Gmeiner P, and Prante O. Synthesis and Evaluation of a ${ }^{18} \mathrm{~F}-$ Labeled Diarylpyrazole Glycoconjugate for the Imaging of NTS1-Positive Tumors. J Med Chem 2013;56:9361-5.

[11] Maschauer S, Haubner R, Kuwert T, and Prante O. ${ }^{18}$ F-Glyco-RGD Peptides for PET Imaging of Integrin Expression: Efficient Radiosynthesis by Click Chemistry and Modulation of Biodistribution by Glycosylation. Mol Pharm 2014;11:505-15.

[12] Maschauer S and Prante O. A series of 2-O-trifluoromethylsulfonyl-D-mannopyranosides as precursors for concomitant ${ }^{18} \mathrm{~F}$-labeling and glycosylation by click chemistry. Carbohydr Res 2009;344:753-61.

[13] Maschauer S and Prante O. Sweetening Pharmaceutical Radiochemistry by ${ }^{18} \mathrm{~F}$ Fluoroglycosylation: A Short Review. BioMed Research Int 2014;2014:214748.

[14] Namavari M, Cheng Z, Zhang R, De A, Levi J, Hoerner JK, et al. A Novel Method for Direct Site-Specific Radiolabeling of Peptides Using $\left[{ }^{18}\right.$ F]FDG. Bioconjugate Chem 2009;20:432-6.

[15] Rashidian M, Keliher EJ, Dougan M, Juras PK, Cavallari M, Wojtkiewicz GR, et al. Use of ${ }^{18}$ F-2-Fluorodeoxyglucose to Label Antibody Fragments for Immuno-Positron Emission Tomography of Pancreatic Cancer. ACS Central Science 2015;1:142-7.

[16] Richter S, Wuest M, Bergman CN, Way JD, Krieger S, Rogers BE, et al. Rerouting the Metabolic Pathway of ${ }^{18}$ F-Labeled Peptides: The Influence of Prosthetic Groups. Bioconjugate Chem 2015;26:201-12.

[17] Wuest F, Berndt M, Bergmann R, van den Hoff J, and Pietzsch J. Synthesis and Application of $\left[{ }^{18} \mathrm{~F}\right]$ FDG-Maleimidehexyloxime $\left(\left[{ }^{18} \mathrm{~F}\right] \mathrm{FDG}-\mathrm{MHO}\right)$ : A $\left[{ }^{18} \mathrm{~F}\right] \mathrm{FDG}-$ Based Prosthetic Group for the Chemoselective ${ }^{18}$ F-Labeling of Peptides and Proteins. Bioconjugate Chem 2008;19:1202-10.

[18] Wuest F, Hultsch C, Berndt M, and Bergmann R. Direct labelling of peptides with 2$\left[{ }^{18}\right.$ F]fluoro-2-deoxy-d-glucose ([ $\left[{ }^{18}\right.$ F $]$ FDG). Bioorg Med Chem Lett 2009; 19:5426-8. 
[19] Dall'Angelo S, Bandaranayaka N, Windhorst AD, Vugts DJ, van der Born D, Onega M, et al. Tumour imaging by Positron Emission Tomography using fluorinase generated 5 - $\left[{ }^{18} \mathrm{~F}\right]$ fluoro-5deoxyribose as a novel tracer. Nucl Med Biol 2013;40:464-70.

[20] Dall'Angelo S, Zhang Q, Fleming IN, Piras M, Schweiger LF, O'Hagan D, et al. Efficient bioconjugation of 5-fluoro-5-deoxy-ribose (FDR) to RGD peptides for positron emission tomography (PET) imaging of $\alpha_{v} \beta_{3}$ integrin receptor. Org Biomol Chem 2013;11:4551-8.

[21] Kiviniemi A, Gardberg M, Autio A, Li X-G, Heuser VD, Liljenbäck H, et al. Feasibility of experimental BT4C glioma models for somatostatin receptor 2-targeted therapies. Acta Oncol 2014;53:1125-34.

[22] Li X-G, Autio A, Ahtinen H, Helariutta K, Liljenback H, Jalkanen S, et al. Translating the concept of peptide labeling with 5-deoxy-5-[ $\left.{ }^{18} \mathrm{~F}\right]$ fluororibose into preclinical practice: ${ }^{18} \mathrm{~F}$-labeling of Siglec-9 peptide for PET imaging of inflammation. Chem Commun (Camb) 2013;49:3682-4.

[23] Li X-G, Dall'Angelo S, Schweiger LF, Zanda M, and O'Hagan D. [ $\left.{ }^{18} \mathrm{~F}\right]-5-$ Fluoro-5deoxyribose, an efficient peptide bioconjugation ligand for positron emission tomography (PET) imaging. Chem Commun (Camb) 2012;48:5247-9.

[24] Li X-G, Helariutta K, Roivainen A, Jalkanen S, Knuuti J, and Airaksinen AJ. Using 5-deoxy-5$\left[{ }^{18}\right.$ F]fluororibose to glycosylate peptides for positron emission tomography. Nat Protoc 2014;9:13845.

[25] Rinne P, Hellberg S, Kiugel M, Virta J, Li X-G, Käkelä M, et al. Comparison of Somatostatin Receptor 2-Targeting PET Tracers in the Detection of Mouse Atherosclerotic Plaques. Mol Imag Biol 2016;18:99-108.

[26] Maschauer S, Einsiedel J, Haubner R, Hocke C, Ocker M, Hübner H, et al. Labeling and Glycosylation of Peptides Using Click Chemistry: A General Approach to ${ }^{18} \mathrm{~F}-$-Glycopeptides as Effective Imaging Probes for Positron Emission Tomography. Angew Chem Int Ed 2010;49:976-9.

[27] Egleton RD and Davis TP. Development of neuropeptide drugs that cross the blood-brain barrier. NeuroRX 2005;2:44-53.

[28] Haubner R, Kuhnast B, Mang C, Weber WA, Kessler H, Wester H-J, et al. [18F]GalactoRGD: Synthesis, Radiolabeling, Metabolic Stability, and Radiation Dose Estimates. Bioconjugate Chem 2004;15:61-9.

[29] Haubner R, Wester H-J, Weber WA, Mang C, Ziegler SI, Goodman SL, et al. Noninvasive Imaging of $\alpha_{\mathrm{v}} \beta_{3}$ Integrin Expression Using ${ }^{18} \mathrm{~F}$-labeled RGD-containing Glycopeptide and Positron Emission Tomography. Cancer Res 2001;61:1781-5.

[30] Schottelius M, Rau F, Reubi JC, Schwaiger M, and Wester H-J. Modulation of Pharmacokinetics of Radioiodinated Sugar-Conjugated Somatostatin Analogues by Variation of Peptide Net Charge and Carbohydration Chemistry. Bioconjugate Chem 2005;16:429-37.

[31] Schottelius M, Wester H-J, Reubi JC, Senekowitsch-Schmidtke R, and Schwaiger M. Improvement of Pharmacokinetics of Radioiodinated $\mathrm{Tyr}^{3}$-Octreotide by Conjugation with Carbohydrates. Bioconjugate Chem 2002;13:1021-30.

[32] Wester H, Schottelius M, Scheidhauer K, Meisetschläger G, Herz M, Rau F, et al. PET imaging of somatostatin receptors: design, synthesis and preclinical evaluation of a novel ${ }^{18} \mathrm{~F}$ labelled, carbohydrated analogue of octreotide. EJNMMI 2003;30:117-22. 
[33] Schweinsberg C, Maes V, Brans L, Bläuenstein P, Tourwé DA, Schubiger PA, et al. Novel Glycated $\left[{ }^{99 \mathrm{~m}} \mathrm{Tc}(\mathrm{CO})_{3}\right]$-Labeled Bombesin Analogues for Improved Targeting of Gastrin-Releasing Peptide Receptor-Positive Tumors. Bioconjugate Chem 2008;19:2432-9.

[34] Moradi SV, Hussein WM, Varamini P, Simerska P, and Toth I. Glycosylation, an effective synthetic strategy to improve the bioavailability of therapeutic peptides. Chem Sci 2016;7:2492500 .

[35] Keinänen O, Li XG, Chenna NK, Lumen D, Ott J, Molthoff CF, et al. A New Highly Reactive and Low Lipophilicity Fluorine-18 Labeled Tetrazine Derivative for Pretargeted PET Imaging. ACS Med Chem Lett 2016;7:62-6.

[36] Schaller H, Weimann G, Lerch B, and Khorana HG. Studies on Polynucleotides. XXIV.1 The Stepwise Synthesis of Specific Deoxyribopolynucleotides (4).2 Protected Derivatives of Deoxyribonucleosides and New Syntheses of Deoxyribonucleoside-3" Phosphates3. J Am Chem Soc 1963;85:3821-7.

[37] Agarwal KL, Yamazaki A, Cashion PJ, and Khorana HG. Chemical synthesis of polynucleotides. Angew Chem Int Ed 1972;11:451-9.

[38] Mali S, Moree WJ, Mitchell M, Widger W, and Bark SJ. Observations on different resin strategies for affinity purification mass spectrometry of a tagged protein. Anal Biochem 2016;515:26-32.

[39] Ramsay SL, Freeman C, Grace PB, Redmond JW, and MacLeod JK. Mild tagging procedures for the structural analysis of glycans. Carbohydr Res 2001;333:59-71.

[40] Glaser M, Morrison M, Solbakken M, Arukwe J, Karlsen H, Wiggen U, et al. Radiosynthesis and Biodistribution of Cyclic RGD Peptides Conjugated with Novel $\left[{ }^{18}\right.$ F $]$ Fluorinated AldehydeContaining Prosthetic Groups. Bioconjugate Chem 2008;19:951-7.

[41] Cheng Z, De Jesus OP, Namavari M, De A, Levi J, Webster JM, et al. Small-Animal PET Imaging of Human Epidermal Growth Factor Receptor Type 2 Expression with Site-Specific ${ }^{18} \mathrm{~F}-$ Labeled Protein Scaffold Molecules. J Nucl Med 2008;49:804-13.

[42] Poethko T, Schottelius M, Thumshirn G, Herz M, Haubner R, Henriksen G, et al.

Chemoselective pre-conjugate radiohalogenation of unprotected mono- and multimeric peptides via oxime formation. Radiochim Acta 2004;92:317.

[43] Flavell RR, Kothari P, Bar-Dagan M, Synan M, Vallabhajosula S, Friedman JM, et al. SiteSpecific ${ }^{18}$ F-Labeling of the Protein Hormone Leptin Using a General Two-Step Ligation

Procedure. J Am Chem Soc 2008;130:9106-12.

[44] Schottelius M, Poethko T, Herz M, Reubi J-C, Kessler H, Schwaiger M, et al. First ${ }^{18}$ F-Labeled Tracer Suitable for Routine Clinical Imaging of sst Receptor-Expressing Tumors Using Positron Emission Tomography. Clin Cancer Res 2004;10:3593-606.

[45] Namavari M, Padilla De Jesus O, Cheng Z, De A, Kovacs E, Levi J, et al. Direct Site-Specific Radiolabeling of an Affibody Protein with $4-\left[{ }^{18} \mathrm{~F}\right]$ Fluorobenzaldehyde via Oxime Chemistry. Mol Imag Biol 2008;10:177-81.

[46] Morris O, Gregory J, Kadirvel M, Henderson F, Blykers A, McMahon A, et al. Development $\&$ automation of a novel $\left[{ }^{18} \mathrm{~F}\right] \mathrm{F}$ prosthetic group, $2-\left[{ }^{18} \mathrm{~F}\right]$-fluoro-3-pyridinecarboxaldehyde, and its application to an amino(oxy)-functionalised A $\beta$ peptide. App Rad Isotop 2016;116:120-7. 
[47] Keinänen O, Mäkilä E, Lindgren R, Virtanen H, Liljenbäck H, Oikonen V, et al. Pretargeted PET imaging of trans-cyclooctene modified porous silicon nanoparticles. ACS Omega 2017;2:62-9.

[48] Keinänen O, Fung K, Pourat J, Jallinoja V, Vivier D, Pillarsetty NK, et al. Pretargeting of internalizing trastuzumab and cetuximab with a ${ }^{18} \mathrm{~F}$-tetrazine tracer in xenograft models. EJNMMI Research 2017;7:95.

[49] Karver MR, Weissleder R, and Hilderbrand SA. Synthesis and evaluation of a series of 1,2,4,5tetrazines for bioorthogonal conjugation. Bioconjugate Chem 2011;22:2263-70.

[50] Schottelius M, Reubi JC, Eltschinger V, Schwaiger M, and Wester H-J. N-Terminal Sugar Conjugation and C-Terminal Thr-for-Thr(ol) Exchange in Radioiodinated $\mathrm{Tyr}^{3}$-octreotide: Effect on Cellular Ligand Trafficking in Vitro and Tumor Accumulation in Vivo. J Med Chem 2005;48:2778-89 
Table 1. Comparison between HPLC-purified and cartridge purified $\left[{ }^{18} \mathrm{~F}\right] \mathbf{6}$.

\begin{tabular}{lcc}
\hline & HPLC-purified [35] & Cartridge purified \\
\hline Yield $^{\mathrm{a}}(\%)$ & $50.5 \pm 1.7$ & $73 \pm 7$ \\
Synthesis time (min) & 120 & 95 \\
Molar activity $(\mathrm{GBq} / \mu \mathrm{mol})$ & 800 & 800 \\
Radiochemical purity $(\%)$ & $>99$ & $>99$ \\
\hline \multicolumn{2}{l}{ a Decay-corrected to the start of synthesis }
\end{tabular}


Scheme 1. Oxime formation using $\left[{ }^{18} \mathrm{~F}\right] \mathrm{FDR}\left(\left[{ }^{18} \mathrm{~F}\right] \mathbf{3}\right)$ and $\left[{ }^{18} \mathrm{~F}\right] \mathrm{FDG}\left(\left[{ }^{18} \mathrm{~F}\right] \mathbf{1 0}\right)$ as prosthetic groups to radiolabel two aminooxy functionalized compounds, tetrazine derivative (4) and PSMA (prostate specific membrane antigen) inhibitor (5). Yield refers to decay-corrected yield. $\mathrm{RCP}=$ radiochemical purity.

Figure 1. Schematic presentation of the synthetic and purification steps during $\left[{ }^{18} \mathrm{~F}\right] \mathrm{FDR}$ and $\left[{ }^{18} \mathrm{~F}\right] \mathrm{FDG}$ radiosynthesis and ${ }^{18} \mathrm{~F}$-fluoroglycosylation via oxime formation.

Fig. 2. HPLC chromatograms of the reaction mixture and the intermediates during synthesis of $\left[{ }^{18} \mathrm{~F}\right] \mathrm{FDR}\left(\left[{ }^{18} \mathrm{~F}\right] 3\right)$ after A) fluorination, B) reaction with DMT-Cl, C) C18 purification, and D) deprotection. Top row: ultraviolet (UV) absorbance at $254 \mathrm{~nm}$. Bottom row: radioactivity detector.

Fig. 3. HPLC chromatograms of the reaction mixture and the intermediates during synthesis of $\left[{ }^{18} \mathrm{~F}\right] \mathrm{FDG}\left(\left[{ }^{18} \mathrm{~F}\right] \mathbf{1 0}\right)$ after A) fluorination, B) reaction with DMT-Cl, C) C18 purification and deprotection. Top row: ultraviolet (UV) absorbance at $254 \mathrm{~nm}$. Bottom row: radioactivity detector.

Fig. 4. Oxime formation between $\left[{ }^{18} \mathrm{~F}\right] \mathrm{FDR}\left(\left[{ }^{18} \mathrm{~F}\right] \mathbf{3}\right)$ or $\left[{ }^{18} \mathrm{~F}\right] \mathrm{FDG}\left(\left[{ }^{18} \mathrm{~F}\right] \mathbf{1 0}\right)$ with aminooxy functionalized tetrazine (A) and aminooxy functionalized PSMA inhibitor (B). The yields (mean \pm s.d.) refer to the amount of $\left[{ }^{18} \mathrm{~F}\right] \mathbf{3}$ or $\left[{ }^{18} \mathrm{~F}\right] \mathbf{1 0}$ converted into the desired ${ }^{18} \mathrm{~F}$-labeled conjugate evaluated with radio-TLC. Dark gray square: conjugation with $\left[{ }^{18} \mathrm{~F}\right] \mathbf{3}$ at room temperature (r.t.), black circle: conjugation with $\left[{ }^{18} \mathrm{~F}\right] \mathbf{1 0}$ at r.t., medium gray triangle up: conjugation with $\left[{ }^{18} \mathrm{~F}\right] \mathbf{1 0}$ at $60{ }^{\circ} \mathrm{C}$, and light gray triangle down: conjugation with $\left[{ }^{18} \mathrm{~F}\right] \mathbf{1 0}$ at $85{ }^{\circ} \mathrm{C}$.

Fig. 5. HPLC chromatograms before and after purification with the AminoLink resin and C18 SepPak cartridge for $\left[{ }^{18} \mathrm{~F}\right]$ FDR conjugated tetrazine $\left(\left[{ }^{18} \mathrm{~F}\right] \mathbf{6}\right)$ and $\left[{ }^{18} \mathrm{~F}\right] \mathrm{FDG}$ conjugated PSMA inhibitor $\left(\left[{ }^{18} \mathrm{~F}\right] 12\right)$. Similar results were obtained with the corresponding $\left[{ }^{18} \mathrm{~F}\right] \mathrm{FDR}$ conjugate $\left[{ }^{18} \mathrm{~F}\right] 7$ (PSMA inhibitor) and $\left[{ }^{18} \mathrm{~F}\right] \mathrm{FDG}$ conjugate $\left[{ }^{18} \mathrm{~F}\right] \mathbf{1 1}$ (tetrazine) (see Supplemental Information Fig. S9.). Top row: ultraviolet (UV) absorbance at $209 \mathrm{~nm}$. Bottom row: radioactivity detector. 


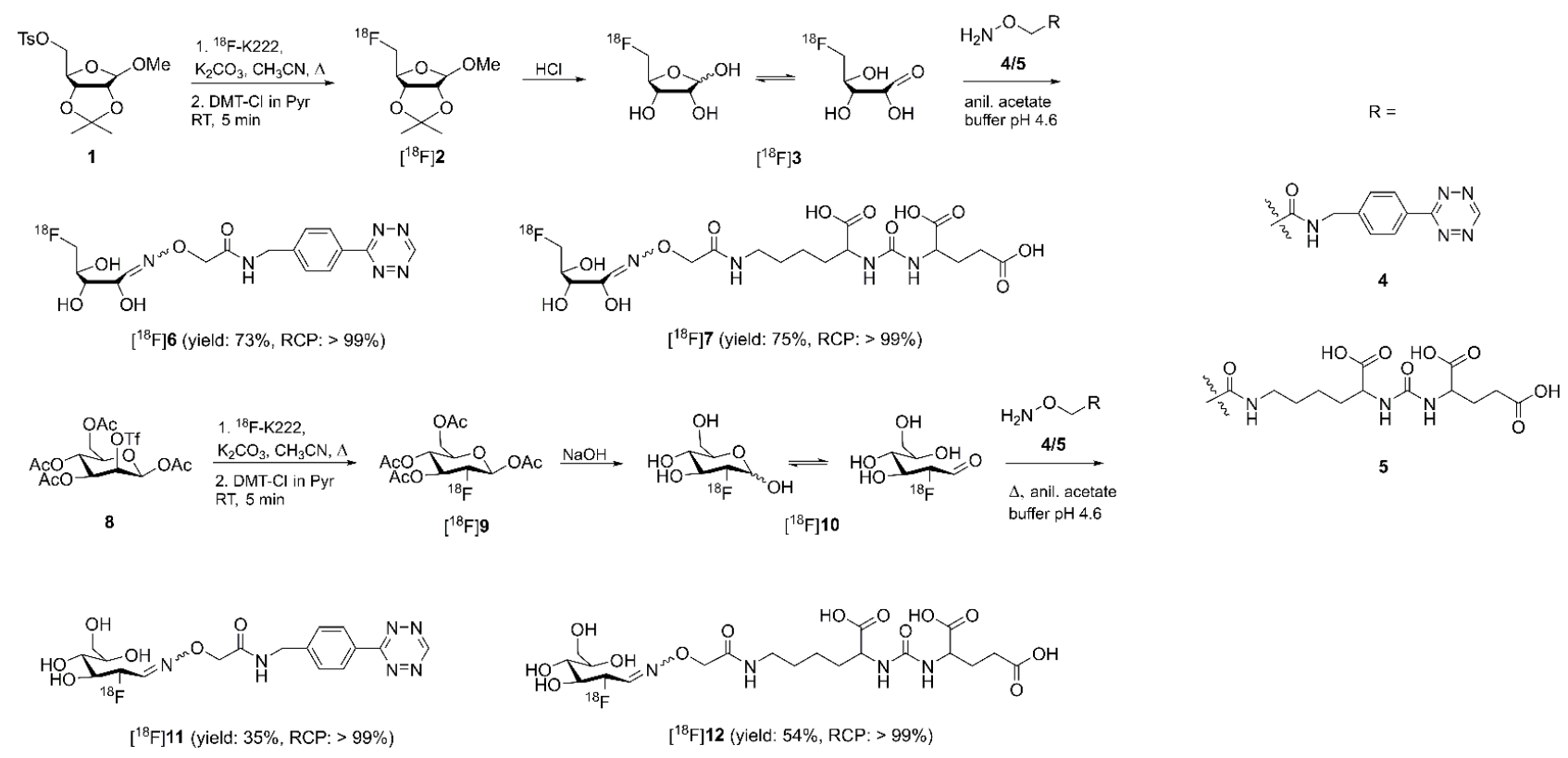

Scheme 1. Oxime formation using $\left[{ }^{18} \mathrm{~F}\right] \mathrm{FDR}\left(\left[{ }^{18} \mathrm{~F}\right] \mathbf{3}\right)$ and $\left[{ }^{18} \mathrm{~F}\right] \mathrm{FDG}\left(\left[{ }^{18} \mathrm{~F}\right] \mathbf{1 0}\right)$ as prosthetic groups to radiolabel two aminooxy functionalized compounds, tetrazine derivative (4) and PSMA (prostate specific membrane antigen) inhibitor (5). Yield refers to decay-corrected yield. $\mathrm{RCP}=$ radiochemical purity. 

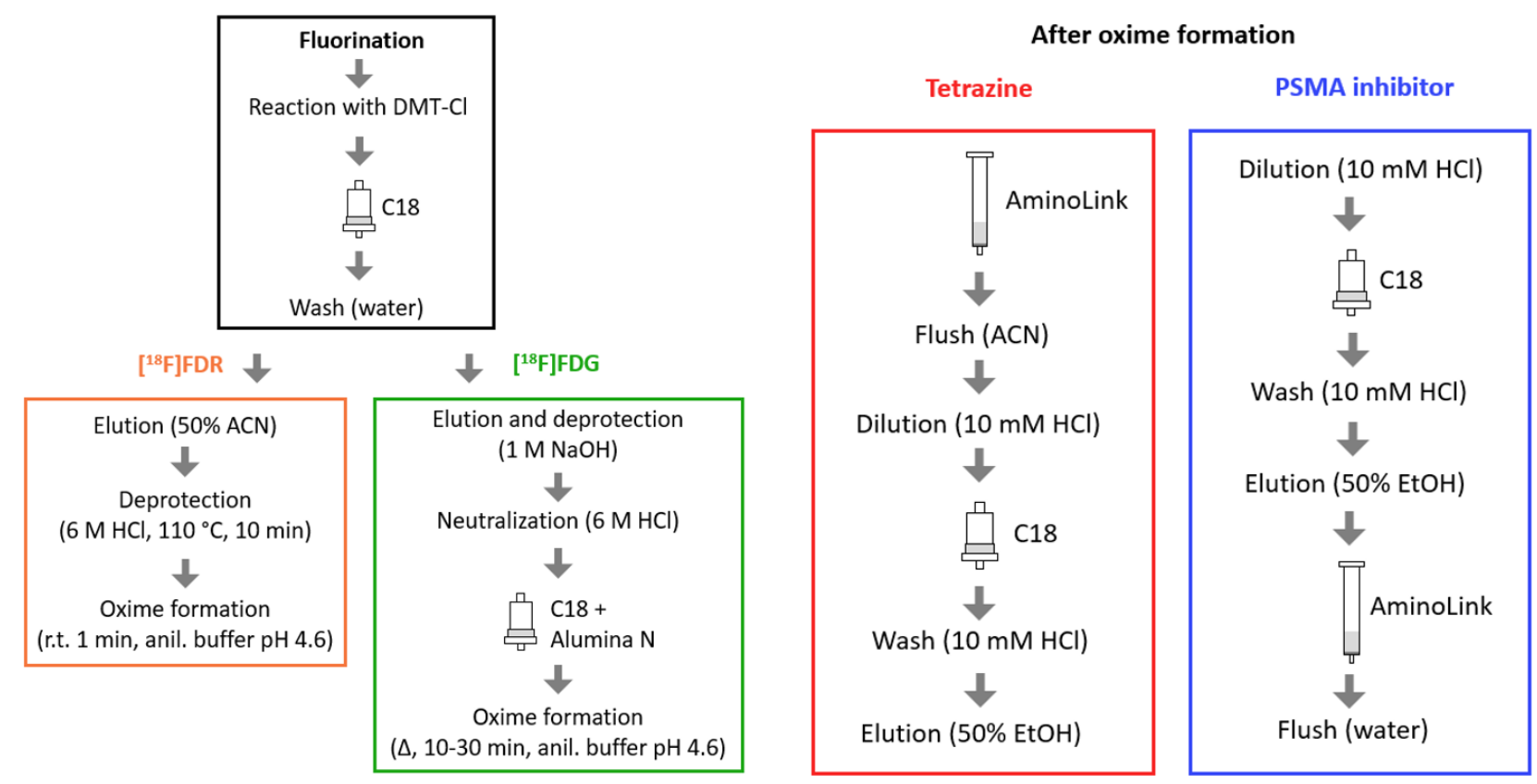

Figure 1. Schematic presentation of the synthetic and purification steps during $\left[{ }^{18} \mathrm{~F}\right] \mathrm{FDR}$ and $\left[{ }^{18} \mathrm{~F}\right] \mathrm{FDG}$ radiosynthesis and ${ }^{18} \mathrm{~F}$-fluoroglycosylation via oxime formation. 
A. After fluorination
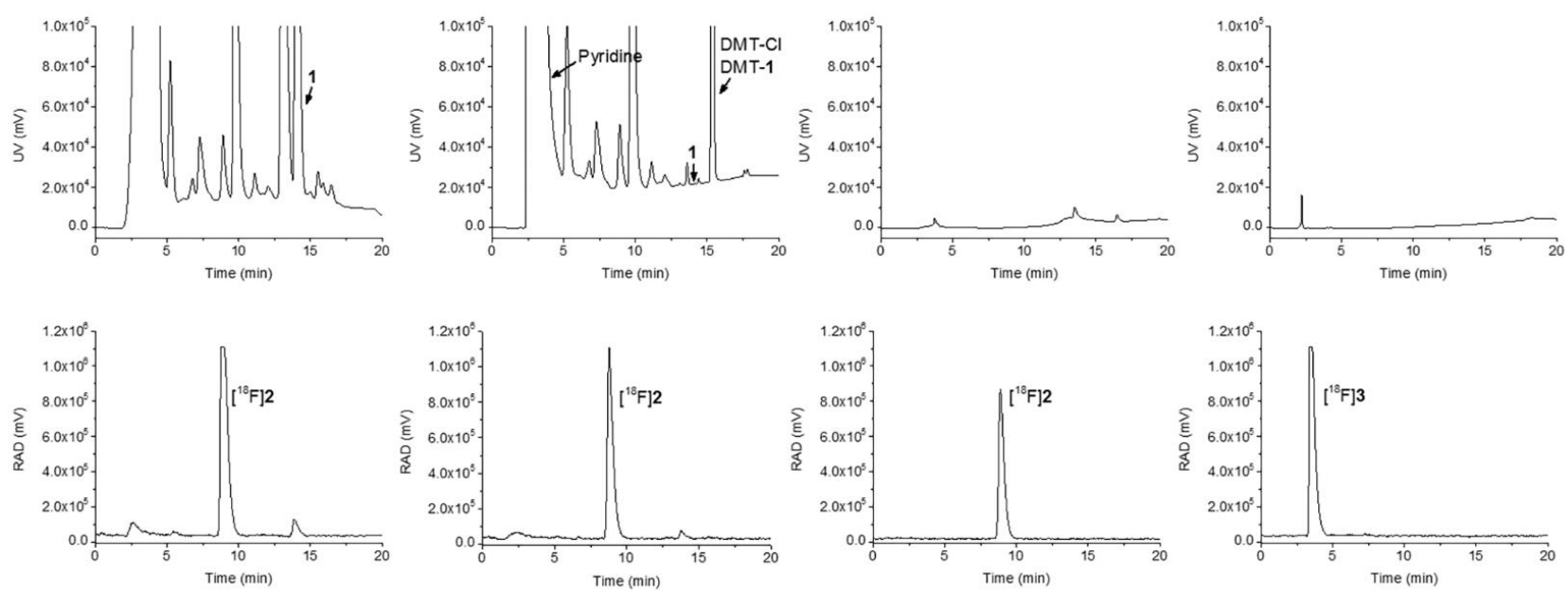

Fig. 2. HPLC chromatograms of the reaction mixture and the intermediates during synthesis of $\left[{ }^{18} \mathrm{~F}\right] \mathrm{FDR}\left(\left[{ }^{18} \mathrm{~F}\right] 3\right)$ after A) fluorination, B) reaction with DMT-Cl, C) C18 purification, and D) deprotection. Top row: ultraviolet (UV) absorbance at $254 \mathrm{~nm}$. Bottom row: radioactivity detector. 
A. After fluorination

B. After DMT-Cl

C. After C18 \& deprotection
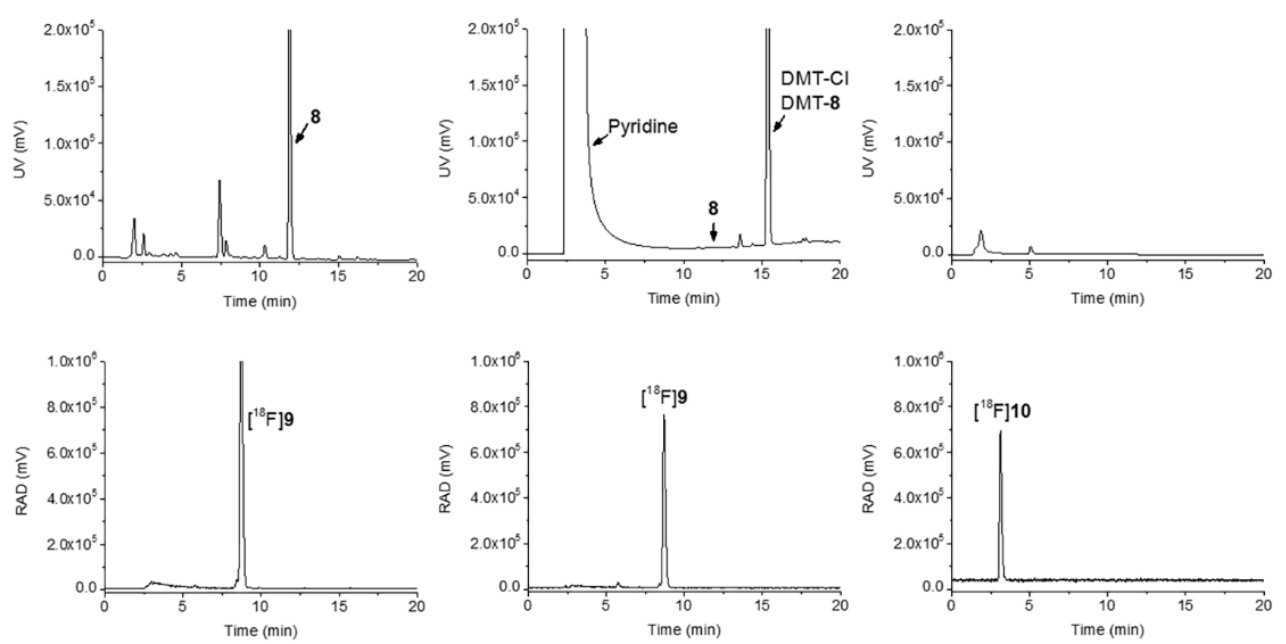

Fig. 3. HPLC chromatograms of the reaction mixture and the intermediates during synthesis of $\left[{ }^{18} \mathrm{~F}\right] \mathrm{FDG}\left(\left[{ }^{18} \mathrm{~F}\right] \mathbf{1 0}\right)$ after A) fluorination, B) reaction with DMT-Cl, C) C18 purification and deprotection. Top row: ultraviolet (UV) absorbance at $254 \mathrm{~nm}$. Bottom row: radioactivity detector. 

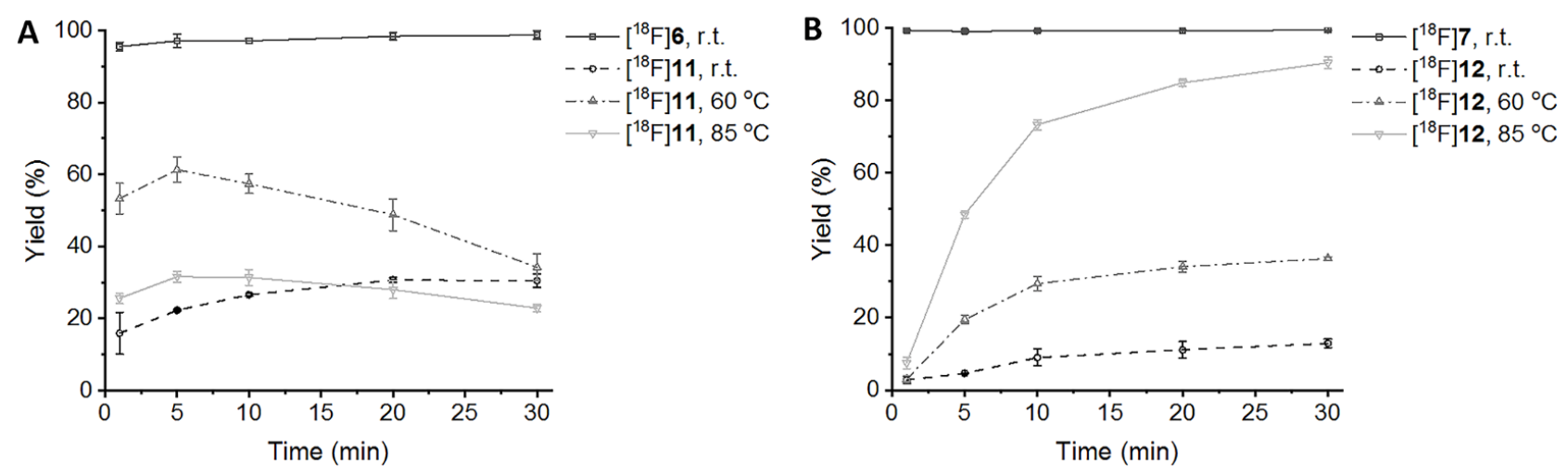

Fig. 4. Oxime formation between $\left[{ }^{18} \mathrm{~F}\right] \mathrm{FDR}\left(\left[{ }^{18} \mathrm{~F}\right] \mathbf{3}\right)$ or $\left[{ }^{18} \mathrm{~F}\right] \mathrm{FDG}\left(\left[{ }^{18} \mathrm{~F}\right] \mathbf{1 0}\right)$ with aminooxy functionalized tetrazine (A) and aminooxy functionalized PSMA inhibitor (B). The yields (mean \pm s.d.) refer to the amount of $\left[{ }^{18} \mathrm{~F}\right] \mathbf{3}$ or $\left[{ }^{18} \mathrm{~F}\right] \mathbf{1 0}$ converted into the desired ${ }^{18} \mathrm{~F}$-labeled conjugate evaluated with radio-TLC. Dark gray square: conjugation with $\left[{ }^{18} \mathrm{~F}\right] \mathbf{3}$ at room temperature (r.t.), black circle: conjugation with $\left[{ }^{18} \mathrm{~F}\right] \mathbf{1 0}$ at r.t., medium gray triangle up: conjugation with $\left[{ }^{18} \mathrm{~F}\right] \mathbf{1 0}$ at $60{ }^{\circ} \mathrm{C}$, and light gray triangle down: conjugation with $\left[{ }^{18} \mathrm{~F}\right] \mathbf{1 0}$ at $85{ }^{\circ} \mathrm{C}$. 
Before purification After purification Before purification After purification
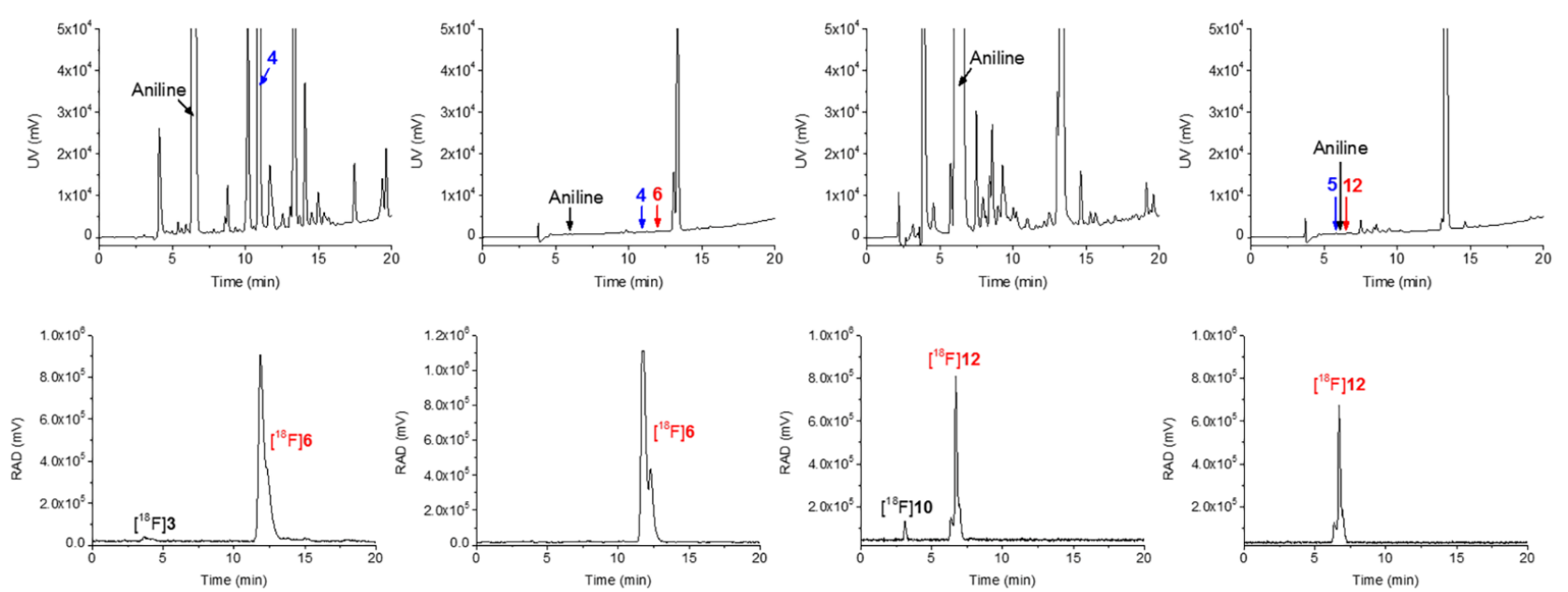

Fig. 5. HPLC chromatograms before and after purification with the AminoLink resin and C18 SepPak cartridge for $\left[{ }^{18} \mathrm{~F}\right]$ FDR conjugated tetrazine $\left(\left[{ }^{18} \mathrm{~F}\right] \mathbf{6}\right)$ and $\left[{ }^{18} \mathrm{~F}\right] \mathrm{FDG}$ conjugated PSMA inhibitor $\left(\left[{ }^{18} \mathrm{~F}\right] \mathbf{1 2}\right)$. Similar results were obtained with the corresponding $\left[{ }^{18} \mathrm{~F}\right] \mathrm{FDR}$ conjugate $\left[{ }^{18} \mathrm{~F}\right] 7$ (PSMA inhibitor) and $\left[{ }^{18} \mathrm{~F}\right] \mathrm{FDG}$ conjugate $\left[{ }^{18} \mathrm{~F}\right] \mathbf{1 1}$ (tetrazine) (see Supplemental Information Fig. S9.). Top row: ultraviolet (UV) absorbance at $209 \mathrm{~nm}$. Bottom row: radioactivity detector. 
Supplemental information:

Efficient cartridge purification for producing high molar activity ${ }^{18} \mathrm{~F}$-glycoconjugates via oxime formation

Outi Keinänen, ${ }^{1}$ Denisa Partelová,,${ }^{1,2}$ Osku Alanen, ${ }^{1}$ Maxim Antopolsky, ${ }^{3}$ Mirkka Sarparanta,,${ }^{1}$ Anu J. Airaksinen ${ }^{1, *}$

${ }^{1}$ Department of Chemistry - Radiochemistry, University of Helsinki, Helsinki, Finland

${ }^{2}$ Department of Ecochemistry and Radioecology, Faculty of Natural Sciences, University of Ss. Cyril and Methodius in Trnava, Trnava, Slovakia

${ }^{3}$ Division of Pharmaceutical Biosciences, Faculty of Pharmacy, University of Helsinki, Helsinki, Finland

For correspondence contact: Anu Airaksinen, Department of Chemistry - Radiochemistry, University of Helsinki, POB 55, FI-00014 University of Helsinki, Finland

Email: anu.airaksinen@helsinki.fi 

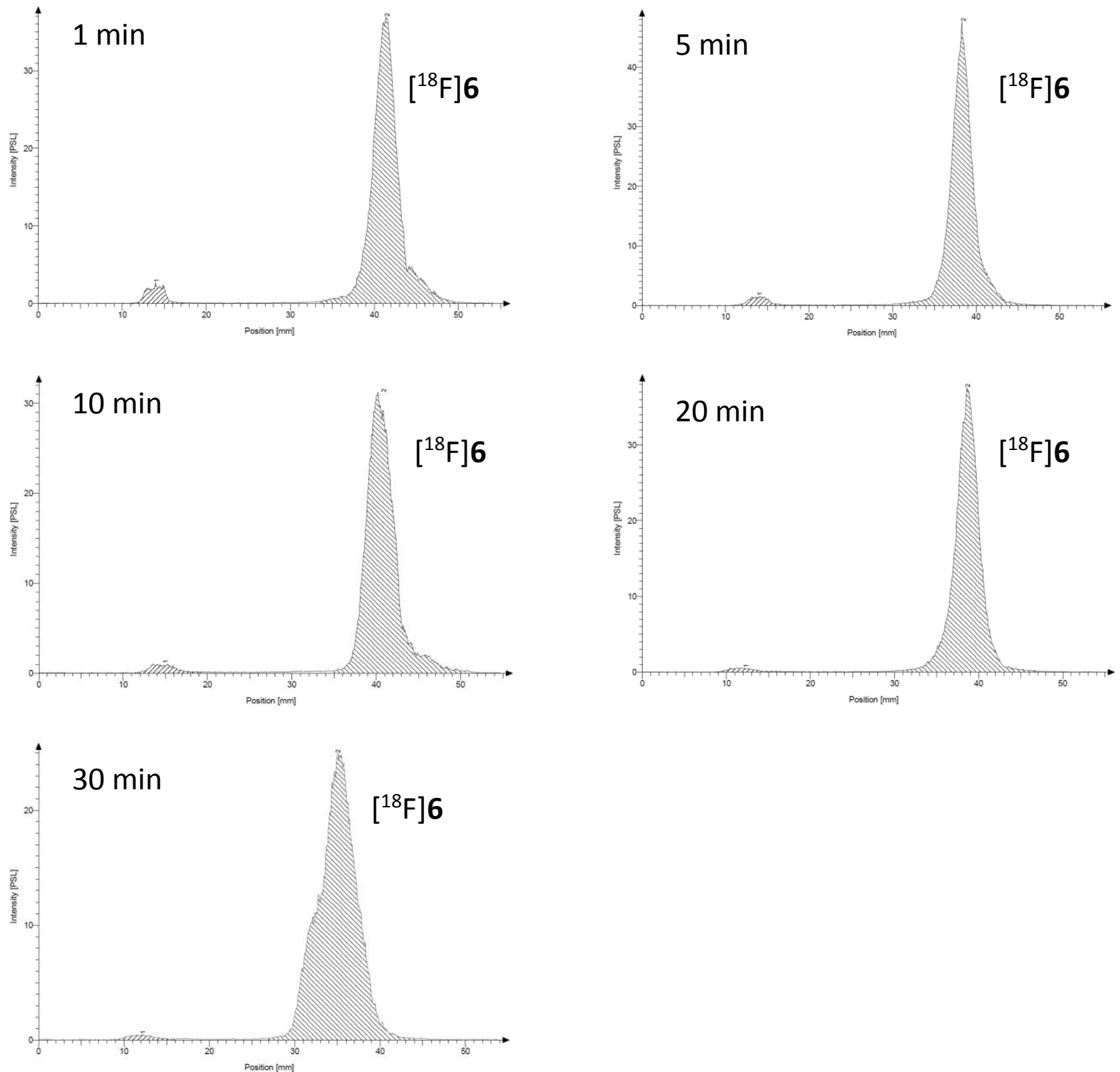

Fig. S1. Radio-TLC chromatograms of $\left[{ }^{18} \mathrm{~F}\right] 6$ at different time points after reaction start. Reaction temperature: r.t. 

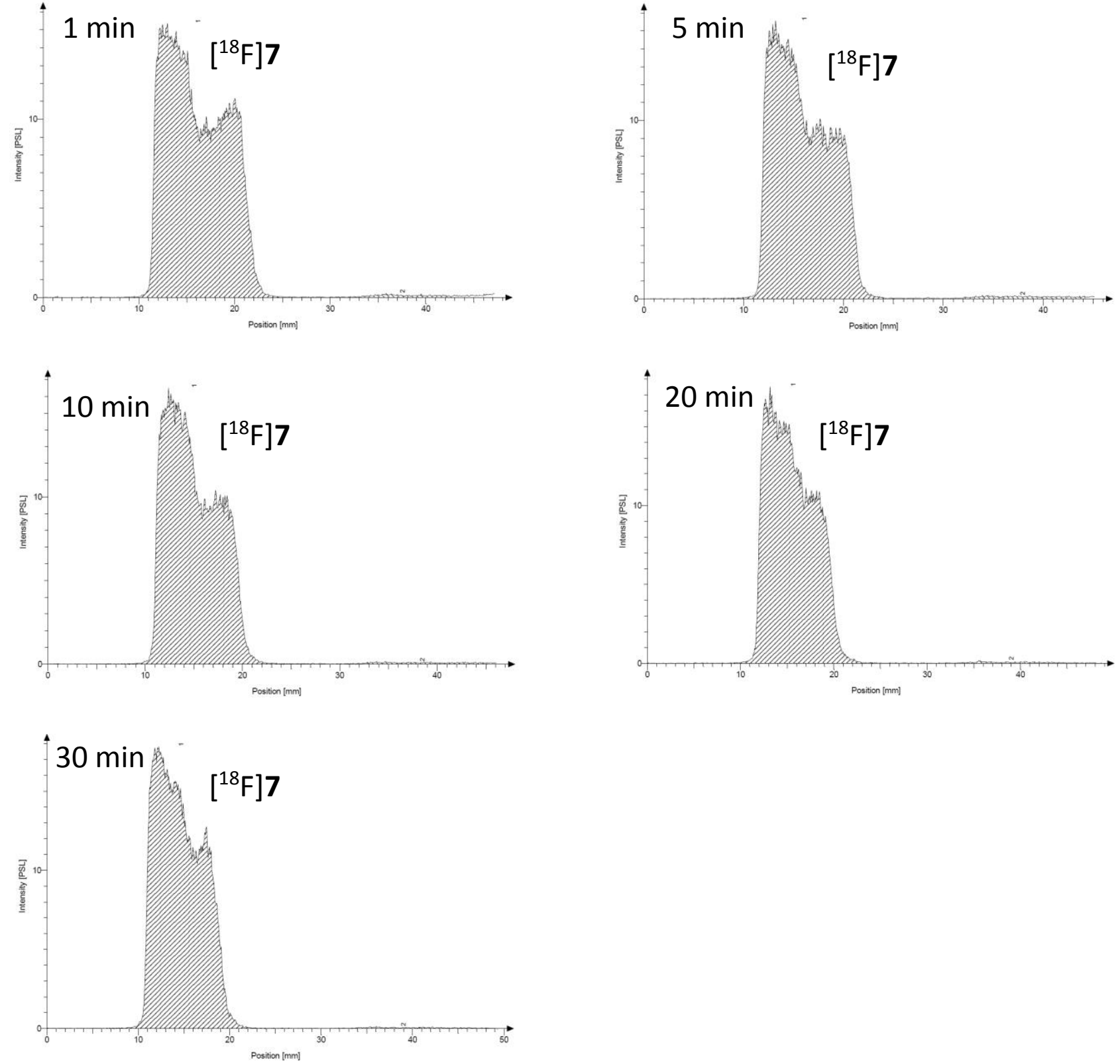

Fig. S2. Radio-TLC chromatograms of $\left[{ }^{18} \mathrm{~F}\right] 7$ at different time points after reaction start. Reaction temperature: r.t. 

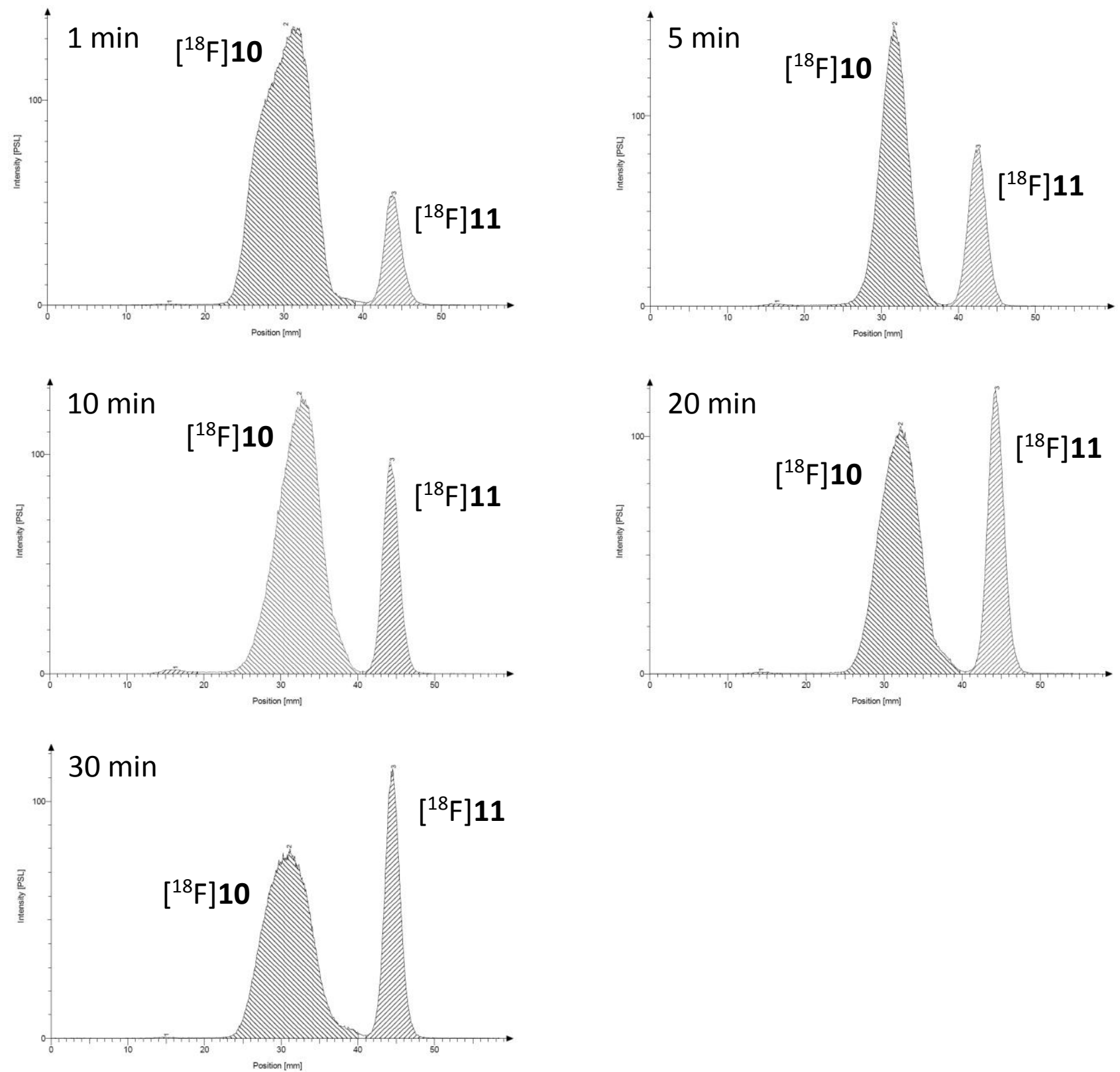

Fig. S3. Radio-TLC chromatograms of $\left[{ }^{18} \mathrm{~F}\right] \mathbf{1 1}$ at different time points after reaction start. Reaction temperature: r.t. 

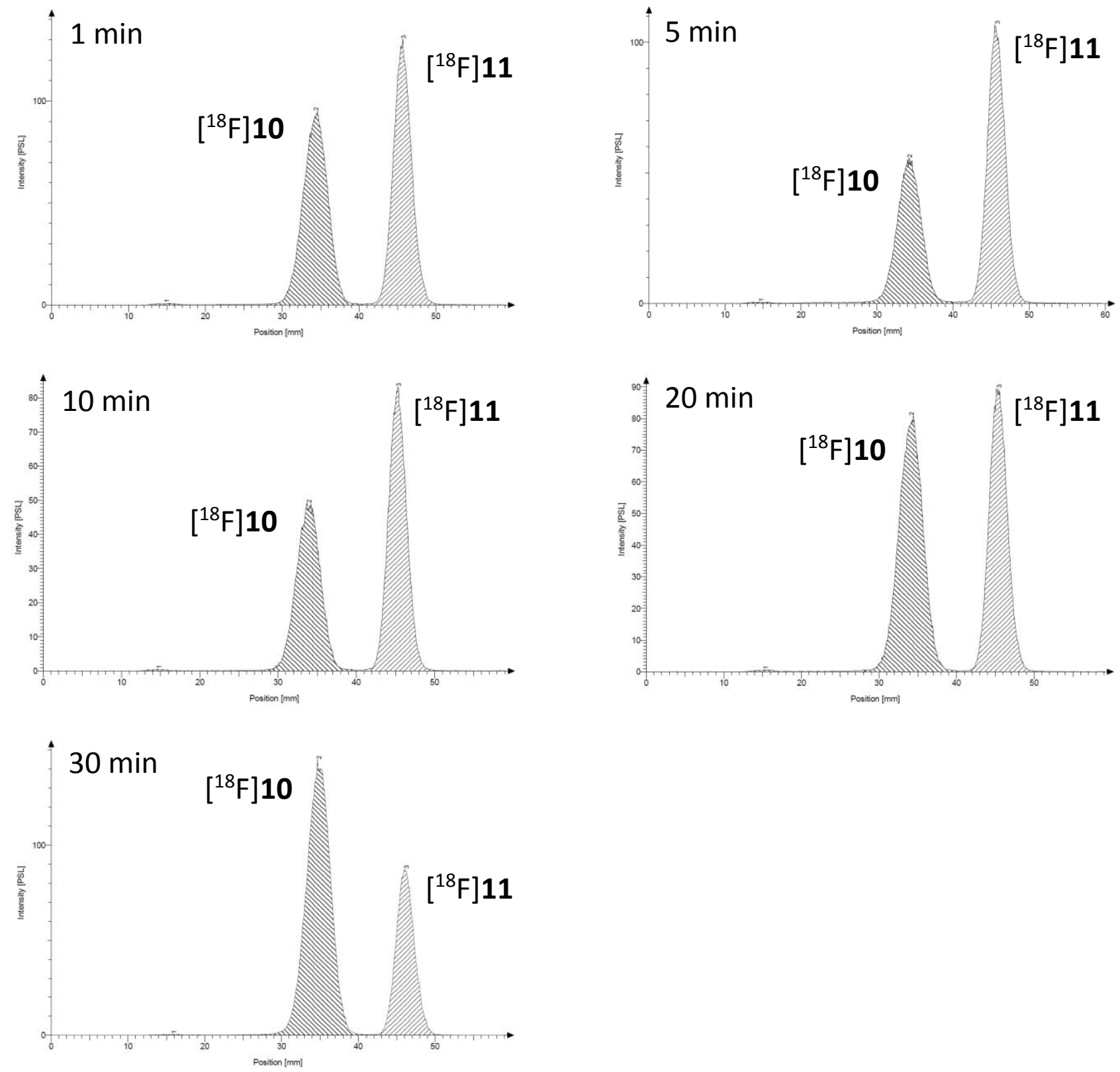

Fig. S4. Radio-TLC chromatograms of $\left[{ }^{18} \mathrm{~F}\right] \mathbf{1 1}$ at different time points after reaction start. Reaction temperature: $60{ }^{\circ} \mathrm{C}$. 

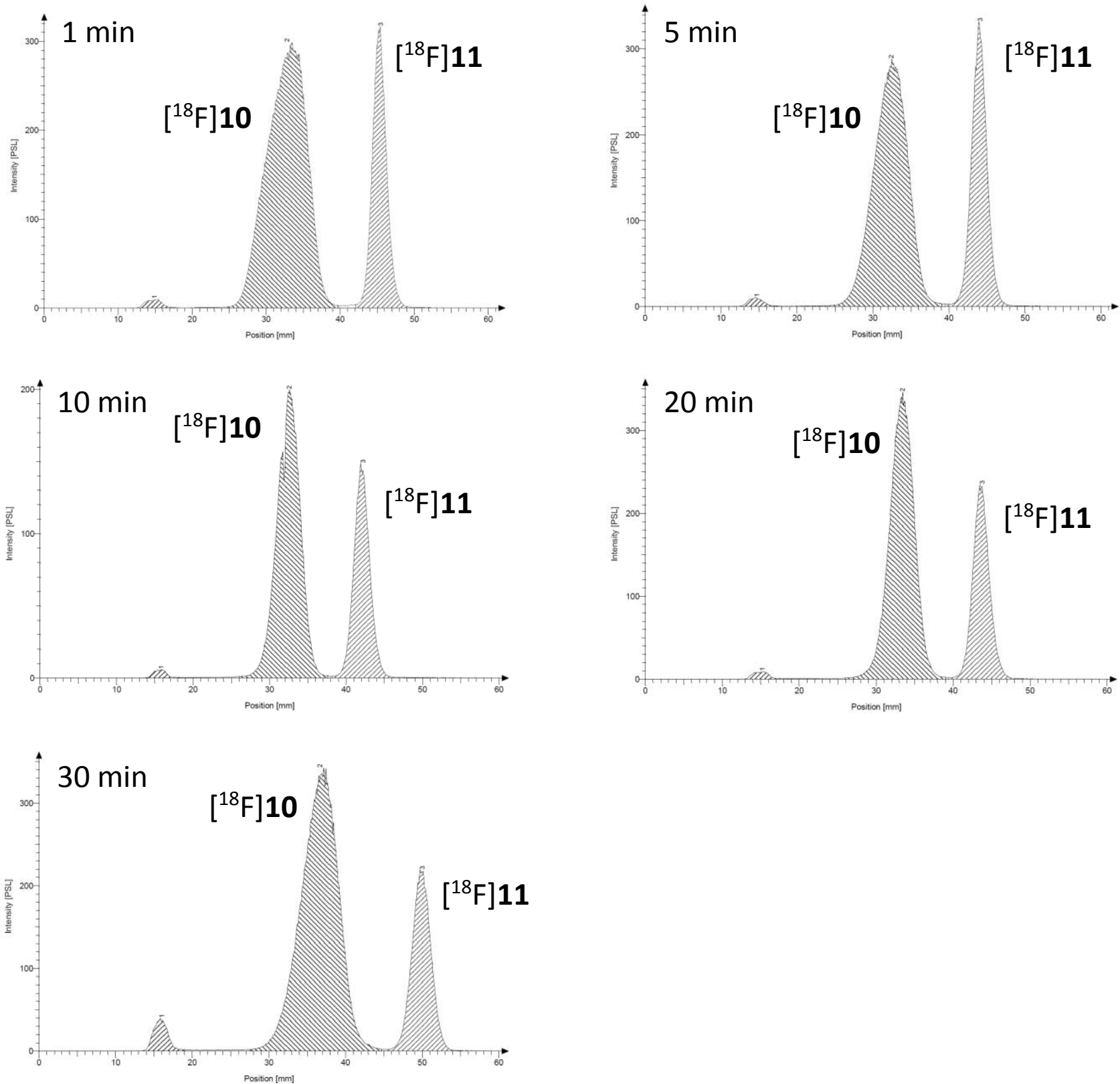

Fig. S5. Radio-TLC chromatograms of $\left[{ }^{18} \mathrm{~F}\right] \mathbf{1 1}$ at different time points after reaction start. Reaction temperature: $85^{\circ} \mathrm{C}$. 

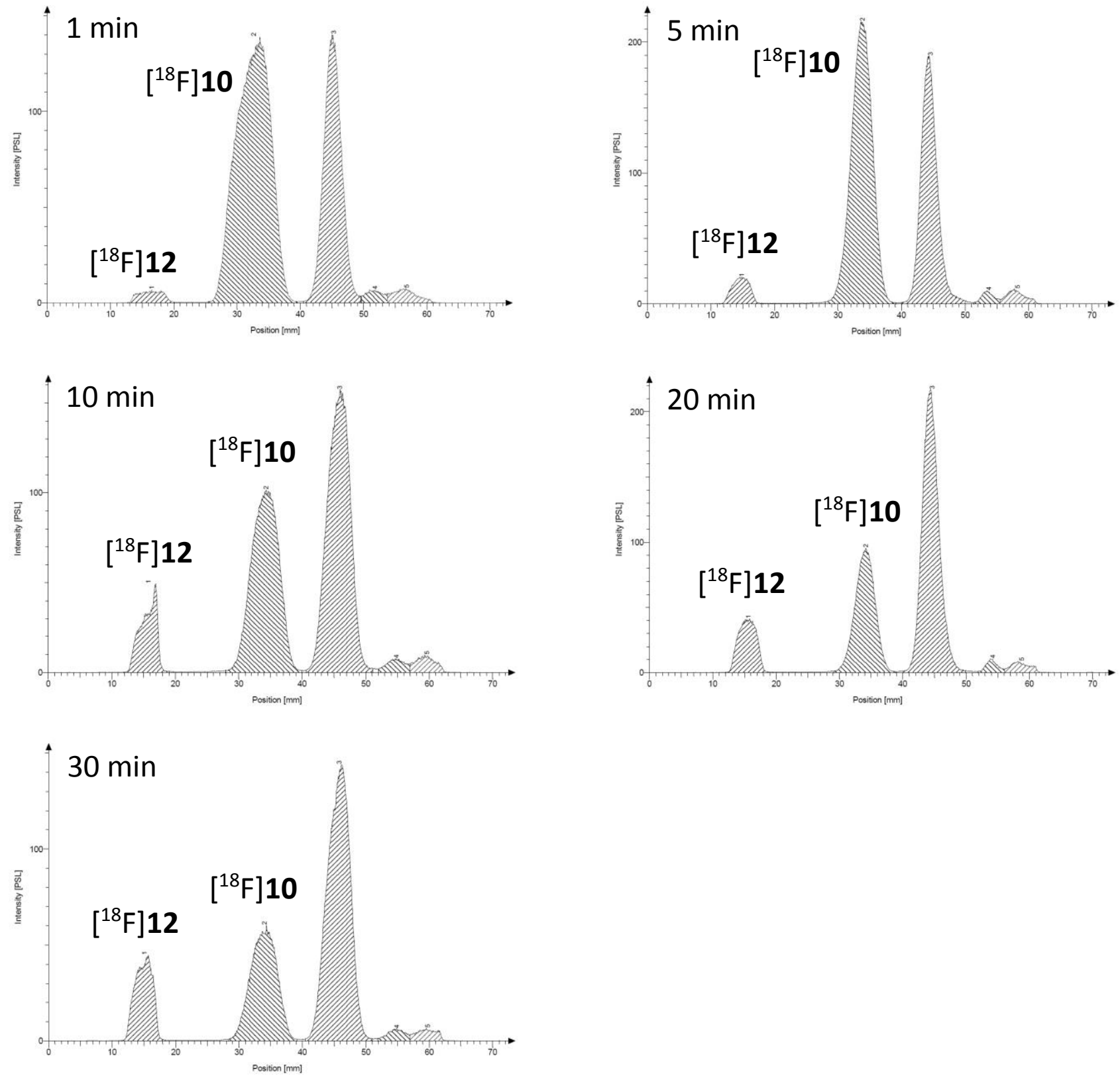

Fig. S6. Radio-TLC chromatograms of $\left[{ }^{18} \mathrm{~F}\right] \mathbf{1 2}$ at different time points after reaction start. Reaction temperature: r.t. 

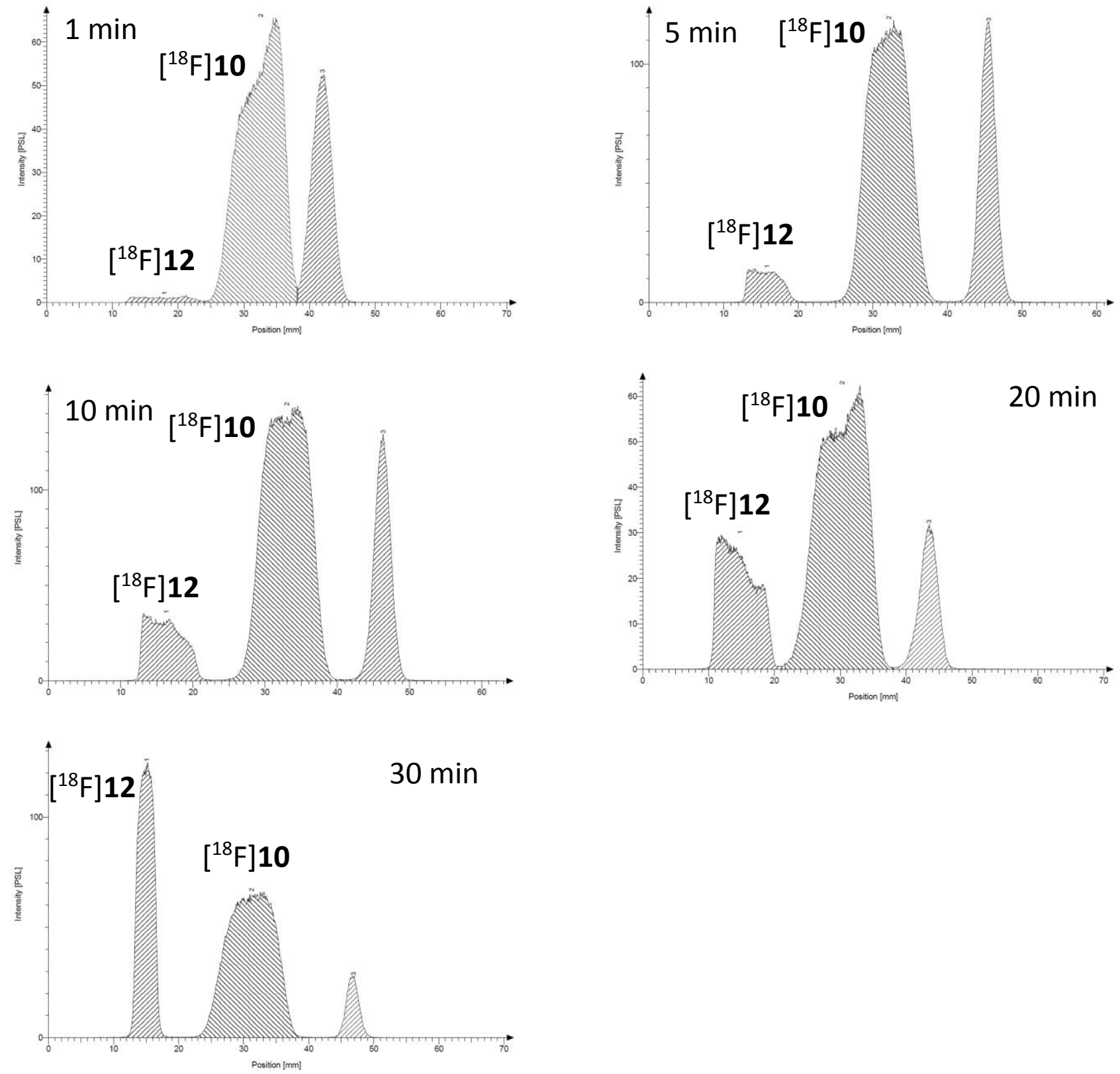

Fig. S7. Radio-TLC chromatograms of $\left[{ }^{18} \mathrm{~F}\right] \mathbf{1 2}$ at different time points after reaction start. Reaction temperature: $60{ }^{\circ} \mathrm{C}$. 

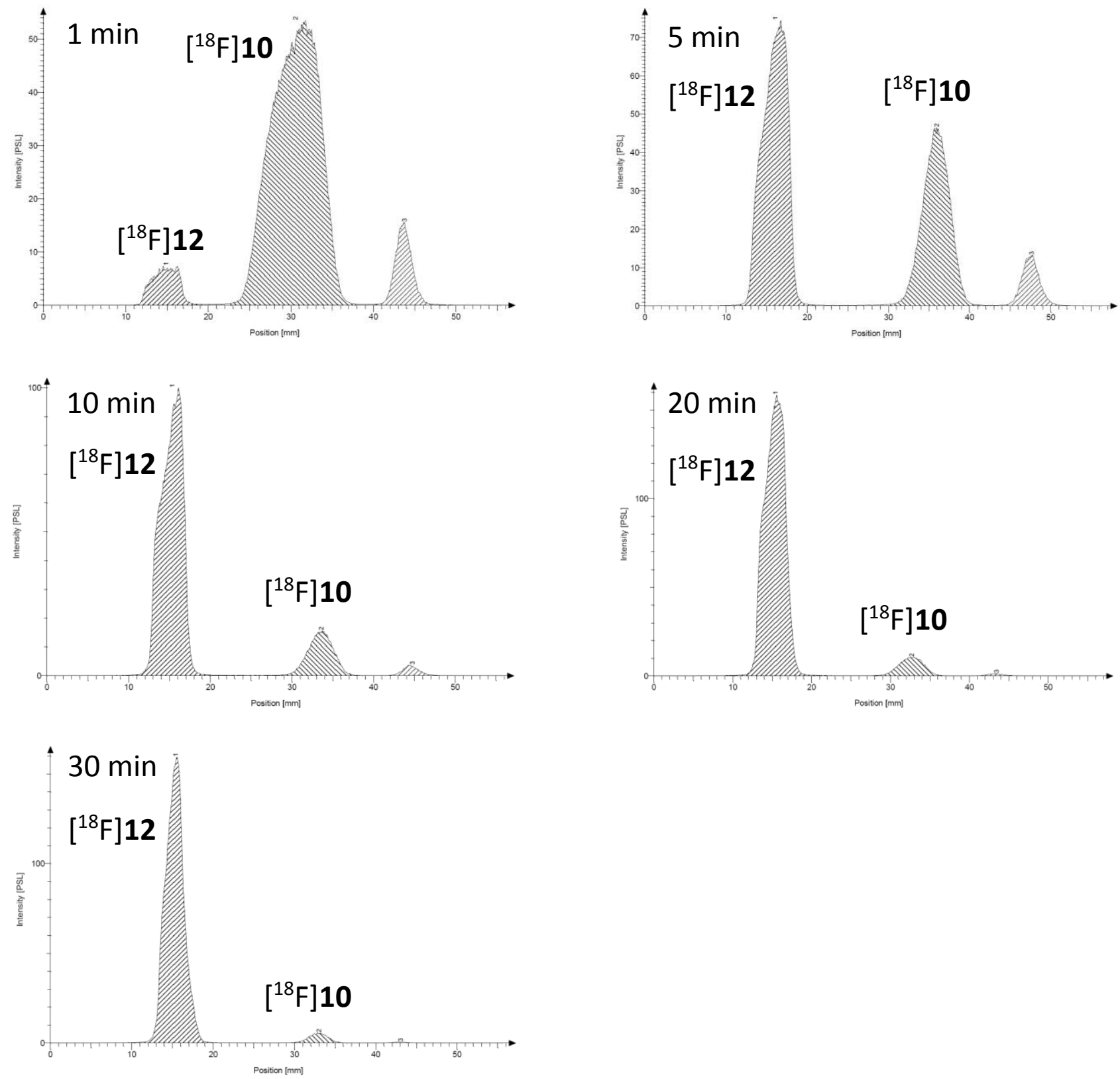

Fig. S8. Radio-TLC chromatograms of $\left[{ }^{18} \mathrm{~F}\right] \mathbf{1 2}$ at different time points after reaction start. Reaction temperature: $85^{\circ} \mathrm{C}$. 


\section{Before purification}
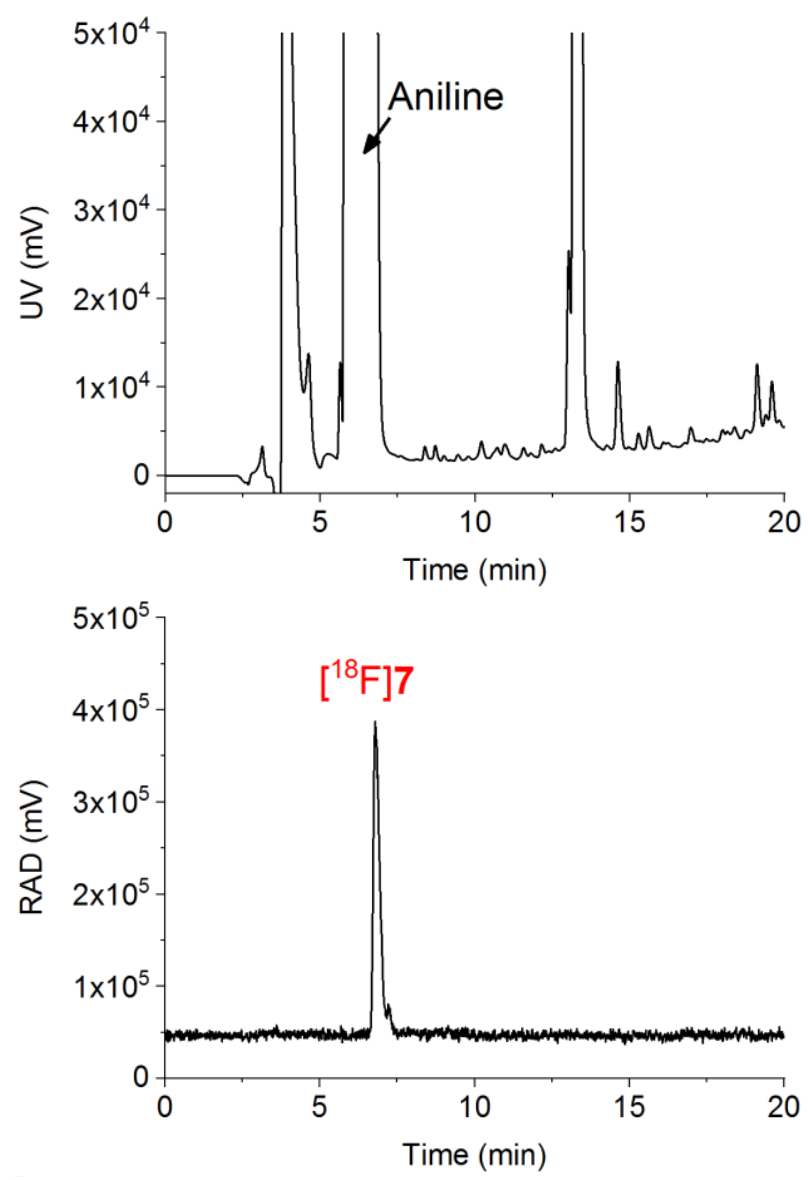

After purification
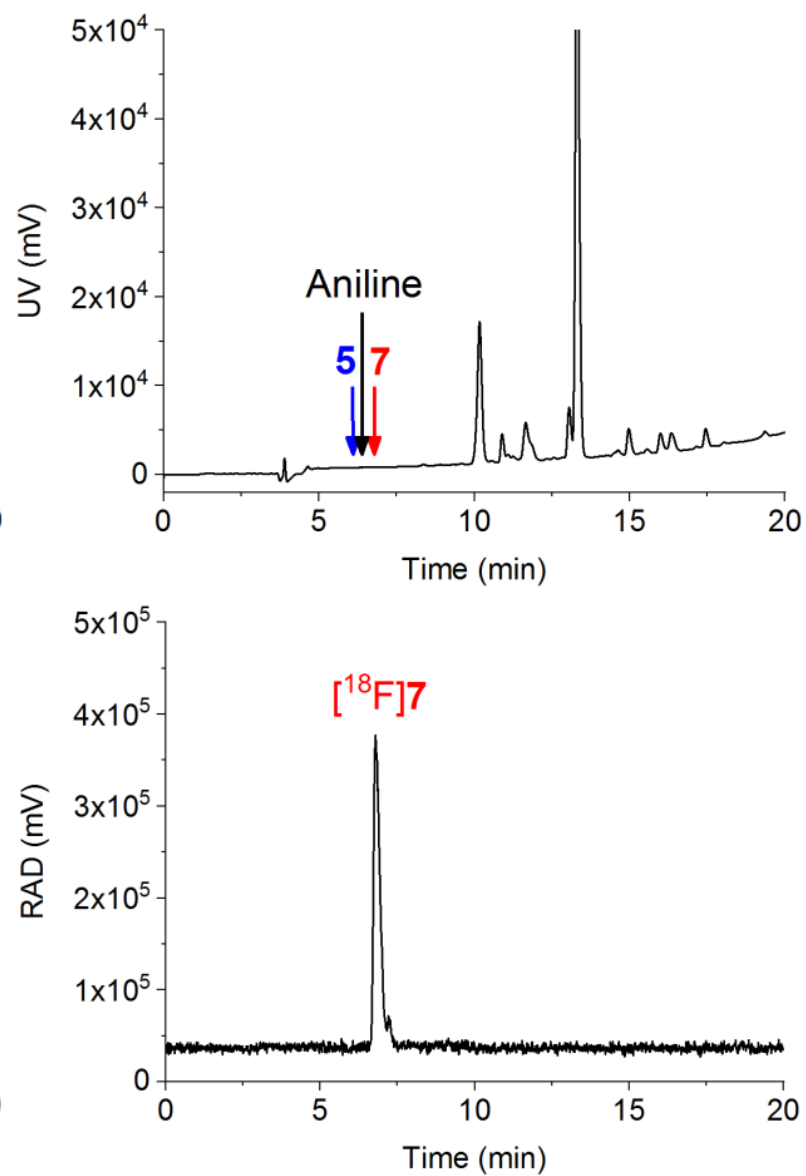

Fig. S9. HPLC chromatograms before and after purification with the AminoLink resin and C18 Sep-Pak cartridge for $\left[{ }^{18} \mathrm{~F}\right]$ FDR conjugated PSMA inhibitor $\left(\left[{ }^{18} \mathrm{~F}\right] 7\right)$. Top row: ultraviolet (UV) absorbance at $209 \mathrm{~nm}$. Bottom row: radioactivity detector. 
Before purification
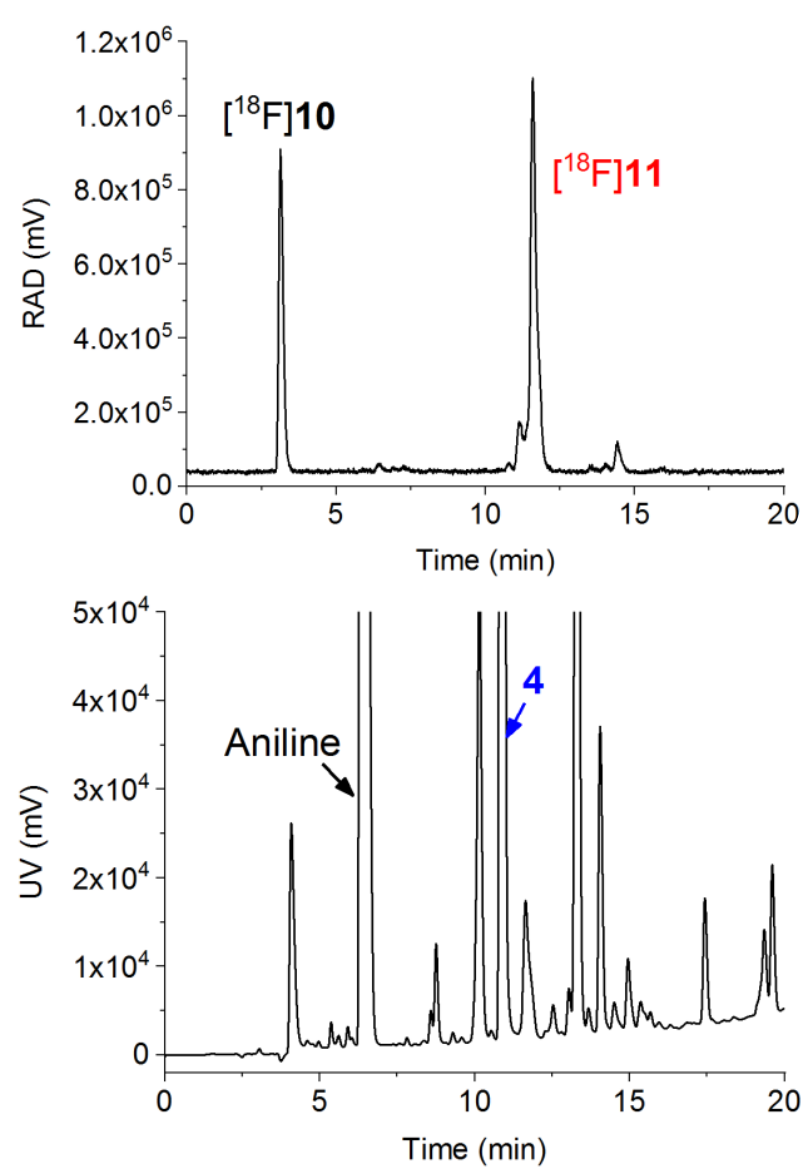

After purification
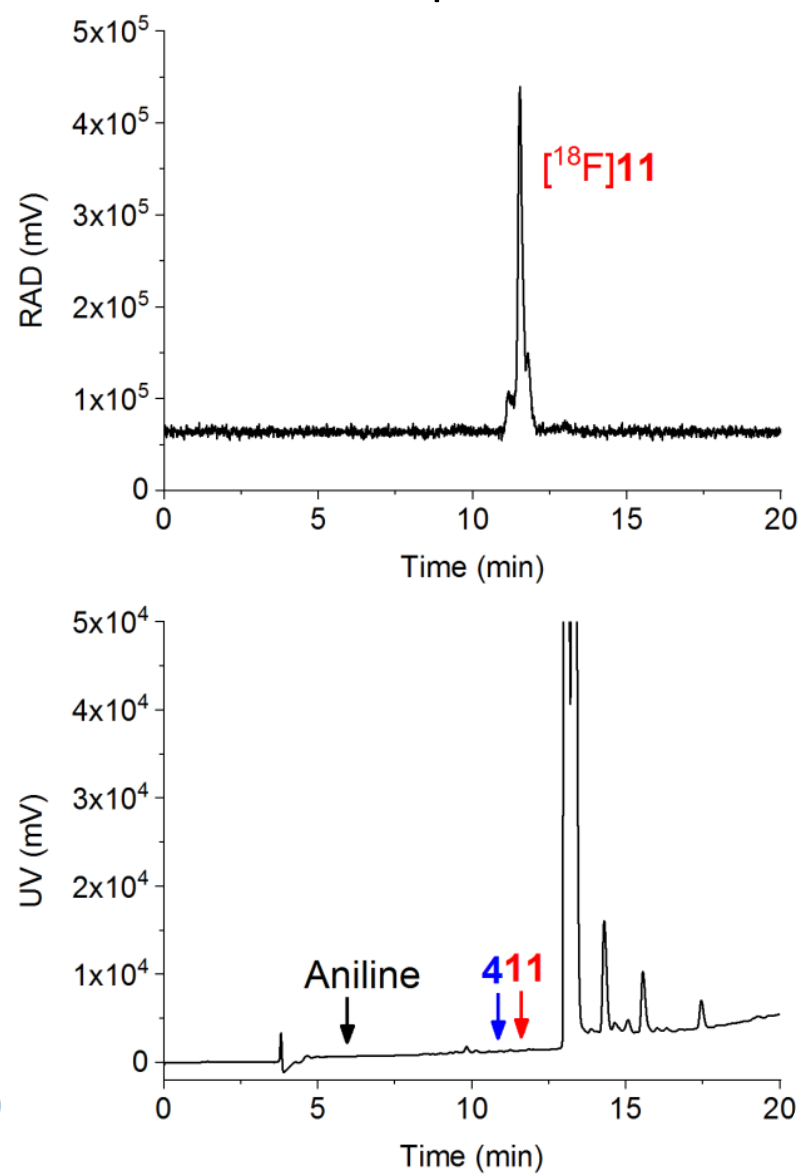

Fig. S10. HPLC chromatograms before and after purification with the AminoLink resin and C18 Sep-Pak cartridge for $\left[{ }^{18} \mathrm{~F}\right] \mathrm{FDG}$ conjugated tetrazine $\left(\left[{ }^{18} \mathrm{~F}\right] \mathbf{1 1}\right)$. Top row: ultraviolet (UV) absorbance at $209 \mathrm{~nm}$. Bottom row: radioactivity detector.

Table S1. Reactivity of HPLC- and cartridge purified $\left[{ }^{18} \mathrm{~F}\right] 6$ with trans-cyclooctene-modified nanoparticles (TCO-NPs). TCO-NPs $(0.005-0.2 \mathrm{mg} / \mathrm{ml})$ were incubated with HPLC-purified and cartridge-purified $\left[{ }^{18} \mathrm{~F}\right] 6$ in PBS pH 7.41 (total volume in each experiment was $1 \mathrm{ml}$ ). The reaction was let to proceed for 5 minutes at room temperature after which the samples were centrifuged (10 $000 \mathrm{~g}, 5 \mathrm{~min}$ ) and radioactivity of the supernatant (unreacted $\left[{ }^{18} \mathrm{~F}\right] 6$ ) and the pellet (reacted $\left[{ }^{18} \mathrm{~F}\right] 6$ with the NPs) were measured in order to determine the yield of the IEDDA reaction.

\begin{tabular}{ccccccc}
\hline $\begin{array}{c}\text { Amount of } \\
\text { TCO-NPs } \\
(\mathrm{mg})\end{array}$ & \multicolumn{2}{c}{$\begin{array}{c}\text { IEDDA yield with } \\
\text { cartridge-purified } \\
{\left[{ }^{18} \mathrm{~F}\right] \mathbf{6}(\%)}\end{array}$} & \multicolumn{3}{c}{$\begin{array}{c}\text { IEDDA yield with } \\
\text { HPLC-purified } \\
{\left[{ }^{18} \mathrm{~F}\right] \mathbf{6}}\end{array}(\%)$} & {$[1]$} \\
\hline 0.005 & 25.56 & \pm & 2.27 & 27.42 & \pm & 2.09 \\
0.010 & 44.07 & \pm & 2.03 & 42.62 & \pm & 2.60 \\
0.020 & 53.34 & \pm & 0.48 & 56.51 & \pm & 2.75 \\
0.100 & 91.01 & \pm & 2.05 & 90.24 & \pm & 0.03 \\
0.200 & 92.81 & \pm & 0.92 & 94.95 & \pm & 1.68 \\
\hline
\end{tabular}




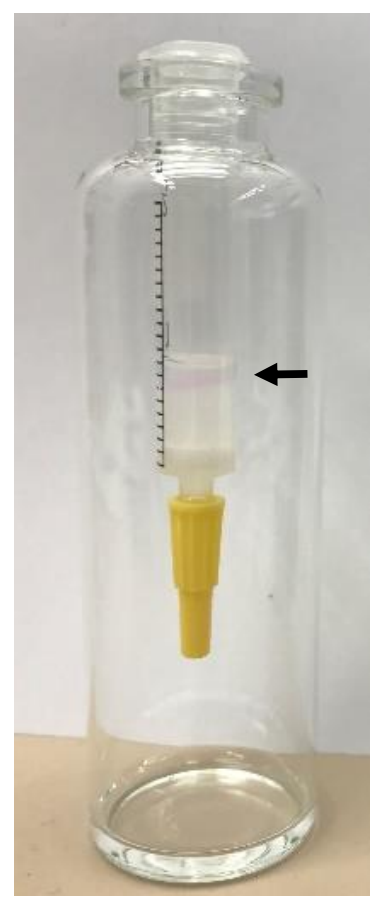

Fig. S12. AminoLink resin after it was used to purify $\left[{ }^{18} \mathrm{~F}\right] 6$. Tetrazines have distinct pink color, and a thin light pink line (arrow) was observed on the AminoLink resin after purification. Based on HPLC, the aminooxy functionalized precursor 4 was quantitatively trapped on the AminoLink resin.

[1] Keinänen O, Mäkilä EM, Lindgren R, Virtanen H, Liljenbäck H, Oikonen V, et al. Pretargeted PET Imaging of trans-Cyclooctene-Modified Porous Silicon Nanoparticles. ACS Omega 2017;2:62-9. 